Article

\title{
Real Estate Market Responses to the COVID-19 Crisis: Which Prospects for the Metropolitan Area of Naples (Italy)?
}

\author{
Pasquale De Toro*(D), Francesca Nocca *(D) and Francesca Buglione* \\ Department of Architecture, University of Naples Federico II, I-80134 Naples, Italy \\ * Correspondence: pasquale.detoro@unina.it (P.D.T.); francesca.nocca@unina.it (F.N.); \\ francesca.buglione@unina.it (F.B.)
}

check for

updates

Citation: De Toro, P.; Nocca, F. Buglione, F. Real Estate Market Responses to the COVID-19 Crisis: Which Prospects for the Metropolitan Area of Naples (Italy)? Urban Sci. 2021, 5, 23. https://doi.org/10.3390/ urbansci5010023

Received: 30 November 2020

Accepted: 19 February 2021

Published: 25 February 2021

Publisher's Note: MDPI stays neutral with regard to jurisdictional claims in published maps and institutional affiliations.

Copyright: (c) 2021 by the authors. Licensee MDPI, Basel, Switzerland. This article is an open access article distributed under the terms and conditions of the Creative Commons Attribution (CC BY) license (https:/ creativecommons.org/licenses/by/ $4.0 /)$

\begin{abstract}
The health emergency caused by the COVID-19 pandemic has affected the entire world since the beginning of 2020, changing living and working conditions. The pandemic has generated a crisis that is having and will continue to have consequences on all sectors of the economy, including the real estate market. During the lockdown period, houses became spaces for both living and working, as well as for leisure activities. Therefore, they were modified to meet the new requirements of communities forced to spend most of their time at home. This will also affect the real estate market in the near future in terms of trends and the characteristics of desirable houses. This research aims to analyse the trends in the residential market in Italy and in particular in the metropolitan area of Naples (Italy). Starting from official sources, the trends of the real estate market, and in particular in the metropolitan area of Naples from 2009 to 2020, have been analysed. Then, two surveys were conducted involving both the community and real estate agents operating in the territory, in order to investigate the effects that COVID-19 has had on the real estate market. The analysis carried out highlights structural changes in the demand for residential properties in the metropolitan area of Naples due to the new requirements as a result of COVID-19.
\end{abstract}

Keywords: real estate market; COVID 19; Italian housing market; cross-tabulation analysis

\section{Introduction}

The COVID-19 pandemic has had (and continues to have) negative impacts beyond the health sector [1-3] and it has generated a crisis worldwide that is having (and will continue to have) consequences on sectors of the economy, including real estate $[4,5]$.

In the first phase of the pandemic, all business activities ceased, except for essential services such as food provision, pharmacies and manufacturing. The closures led to negative impacts on consumption, investments and trade, causing a demand and supply shock [6]. Most people were "stuck" in their own homes because of the "stay-at-home" measures implemented by governments [7]. Citizens began to work, study, exercise, entertain themselves and weave social ties while enclosed within the walls of their domestic spaces. Technology helped people to maintain relationships and has contributed to the preservation of a sense of community, perhaps more rooted than that experienced under normal conditions. Virtual proximity proved to be a "kindly weapon" capable of overcoming the "liquid modernity" on which society has been based [8].

The pandemic crisis has led to the new organisation of activities in terms of urban spaces and mobility, as well as different uses of the spaces inside houses. In a period of a few weeks (at the beginning of the pandemic), cities changed their "faces": citizens were forced to stay indoors and mobility was almost completely restricted, necessitating experimentation with new forms of urban organisation and living in domestic spaces. These new ways of living will, in part, end with the end of the health emergency; however, in some ways, they are likely to become part of our way of life and therefore will not end when the pandemic is over. In fact, the pandemic has only forced us to speed up processes that were already underway. 
After the lockdown, which lasted for three months in Italy from March to May 2020, activities began to restart gradually, leading to the second phase of pandemic management, characterised by containment and coexistence with the virus. The vaccine would lead to the third phase, with the gradual return to "normal life", although in new forms.

The pandemic has changed the way of life of many people, towards the research of new places to live or for new types of sociality. One of the sectors most involved in the rethinking of living spaces is real estate, which is currently the Italian economy's leading sector, accounting for $18 \%$ of GDP [9]. Indeed, due to the health emergency, many people are spending most of their time at home, in dwellings that are sometimes inadequate for living or working. For this reason, a radical and structural change in housing demand (and thus supply) is expected in the coming months.

The new housing requirements that are emerging in this period are also likely to affect the future market in the post-COVID-19 period, as many lifestyles are destined to change and work, study and leisure requirements will no longer be the same as before the pandemic.

According to Stefano Boeri (an important Italian architect) in an interview with the IlSole24Ore economic newspaper on 24 September 2020, smart working, digital growth, increased use of open spaces and desynchronisation of traffic flows will not stop, even when the pandemic is over. He stated that, "They were all trends already underway, but the acceleration is now very strong [...]. If today we spend five days in the office in the city and two days out of the city, I see a future in which we will spend, with greater wellbeing, five days out of the city and we will go two days in the office for task that have to be carry out there" [10].

Today, COVID-19 is placing cities in crisis, meaning in particular that their spatial organisation is not adequate to meet the changes due to COVID-19 [11]. The COVID-19 pandemic, in general, is forcing a reformulation of urban studies in relation to several aspects, including, for example, those related to urban inequalities and mobility, whose criticalities are inevitably coming to light with the health emergency $[12,13]$. However, in the future, other phenomena (i.e., climate change) will cause other crises. For this reason, we need to consider and develop new models that will enable cities to be resilient and manage their fragilities. The new identity of the post-pandemic city today reflects a longawaited transition that looks towards sustainability on multiple levels (energy, environment and society).

This research aims to investigate trends in the Italian residential market, and in particular in the metropolitan area of Naples (Italy). It also aims to identify possible consequences on the real estate market from the national crisis caused by the COVID-19 pandemic. After an overview of recent studies relating to the effects of the pandemic on real estate (Section 2), the methodology and the questionnaire distributed to the community and real estate agents are discussed (Section 3). Then, the analysis of the pre-COVID-19 real estate market is elaborated (Section 4), in Italy (Section 4.1) and, in particular, in the metropolitan area of Naples (Section 4.2). Furthermore, forecasts related to the post-COVID19 real estate market in Italy are presented (Sections 5, 5.1 and 5.2). Data relating to the already observed effects of COVID-19 on the real estate market are presented in Sections 6, 6.1 and 6.2. The results are then deduced and discussed (Sections 7 and 8).

\section{Overview of Recent Studies on the Effects of the Pandemic on the Real Estate Market}

The lockdown has raised a number of issues relating to the changing demand for living spaces. In Italy and around the world, discussions are taking place relating to the effects of COVID-19 on the real estate market. However, few studies have been conducted in recent months to investigate the data that have already been collated on the impacts of the pandemic on the real estate market.

The housing market is experiencing a significant slowdown due to COVID-19. This trend will inevitably affect price also. An Irish study analysing different future scenarios in the real estate market predicts a price decline caused by a decrease in house- 
hold incomes over the next 18 months [6]. This decline has been relatively contained due to the incentives that the Irish government introduced to tackle rising unemployment and the consequent difficulties that families face in terms of paying rent or mortgages. The recovery of demand in the housing market, according to the abovementioned study, will depend on how long these incentives will be in force and the level of strictness in terms of the number and size of mortgages offered by the banks. The strong uncertainty that is characterising this period is tending to dissuade people from buying houses.

A contraction in the volume of housing sales is highlighted in a study on the Turkish real estate market [2]. This study analyses real estate trends from 2010 to 2020, focusing in particular on variations in the period 2019-2020, confirming the negative shock on the real estate market due to the COVID-19 pandemic. The research assumes that the housing market will only reach stability after the pandemic, unlike the commercial real estate market, which will accelerate. Researching possible changes and opportunities following the pandemic, this study suggests that a change is expected in decision making about the planning and construction of settlements and investment approaches.

A UK study has shown how COVID-19 has led to changes in housing demands. For example, the increased prevalence of smart working has led to a growing focus on comfort and quality of the indoor environment. Better thermal insulation, acoustic insulation, visual comfort, indoor air quality and the use of natural light are some of the factors identified by the aforementioned study as buyers' desires for improvement. These elements will lead to greater investments in measures to improve house performances, such as increased thermal or acoustic insulation (which in turn would lead to a reduction in $\mathrm{CO}_{2}$ emissions) [14].

The containment measures implemented to tackle the spread of the virus have caused a decline in economic activity. Therefore, workers whose incomes have decreased (for example, due to payroll subsidies) or even been lost altogether (due to redundancy) have difficulty paying rent, mortgages or taxes related to their real estate. Government measures are therefore needed to avoid an excessive negative shock to the housing market. Governments in several countries are attempting to mitigate these negative impacts by adopting various measures such as protection against dismissal for tenants, mortgage relief, rent freezes and rent subsidies [4].

Another study has investigated the impact of the pandemic on the global economy and real estate [15]. This report analyses the real estate policies that are expected to be implemented after the first phase of the health crisis and develops a possible approach to evaluate the effective short- and long-term actions for the recovery of the sector. The results highlight the need to focus on citizens' income protection programmes, manage health impacts and mitigate the health risk in care homes and healthcare facilities, suggesting co-living building systems and digital communities.

A similar study has been conducted in Italy identifying short-term actions to develop an operational and financial response to mitigate the effects of COVID-19 [16]. This report focuses on the strategies that need to be implemented for the recovery of the real estate market, proposing a managerial approach.

In Italy, other studies have centred on analysis of data from real estate companies, investigating the changes in housing demand after the first phase of COVID-19. A study in the city of Padua, based on a survey, investigated how much COVID-19 had impacted the real estate market from a community perspective (representing demand), focusing on market trends as perceived by users, but it proved to be partially misaligned with the data collected by real estate agencies [17]. The survey included questions relating to buying and selling, rent transactions, market prices, economic availability for investments and the physical-spatial characteristics of houses required by users. In Padua, there was an increase in the number of transactions carried out in the post-lockdown period, higher than in the same period in $2019(+4 \%)$. Therefore, according to the survey, an increase in demand for houses with larger additional spaces emerged and properties with this characteristic could increase in value. The most-requested category of housing is apartments in the historic 
centre ( $+55 \%$ compared to the same period of 2009), with a floor area over $100 \mathrm{sqm}$ and with a terrace $(40 \%)$ or garden $(26 \%)$.

Another line of research focuses on the impacts of COVID-19 on real estate services. Many measures have been adopted by real estate agencies to continue their activities while guaranteeing social distancing precautions during lockdown [18]. Tools such as Skype or Facetime have been used to provide house tours, minimising the risk of infection [5]. Some studies highlight the increasing role of technology in real estate and collect a series of experimentations from real estate agencies on future changes that could be implemented, as well as different initiatives (i.e., a COVID-19 management model, prop-tech and eservices, the Internet of Things and land registry and building information modelling) or a live virtual inspection service aimed at drafting real estate evaluations remotely through a teleconference system, to ensure concrete support for customers even in the current emergency period $[2,19]$.

As well as the abovementioned studies, a number of conferences and seminars on this topic have been held in 2020; major players in the real estate national market attended these meetings, discussing possible ways to recover from the crisis. From these conferences, it emerged that urban regeneration could be considered the driving force of the postCOVID-19 real estate economy [20].

Recent studies have focused on the analysis of data obtained by real estate agencies in relation to changes in buyer requests. They also discuss strategies that could be activated from a financial and managerial point of view. The present study focuses on the analysis of buying and selling, and rental trends in the residential market relating to the pre- and post-lockdown periods in order to understand the real impact of COVID-19 on the sector. The study combines information obtained from real estate agencies and the community.

\section{Methodology}

Analysing and understanding the changes in the characteristics required for post COVID-19 housing would support in orienting decision-making policies for urban transformation, investments and the development and localisation of new activities.

To this end, starting from official sources, the trend of the real estate market in Italy, and in particular the residential real estate prices in the metropolitan area of Naples from 2009 to 2020, have been analysed (data also georeferenced by GIS software). Then, the community and the real estate agents linked to the metropolitan area of Naples were involved through a survey. The objective of collecting this information and data is understanding how people's needs in relation to domestic spaces are being modified and the resulting changes in the real estate market. To this end, two questionnaires were developed.

The development of the survey included five different steps: definition of the territorial boundary for analysis; identification of target groups; development of the questionnaires; distribution of the questionnaires; and deduction and critical analysis of the results.

In particular, the metropolitan area of Naples was chosen as the territorial boundary for this analysis in order to include different zones (from the central zones to the peripheral and suburban areas).

Next, the target groups for the questionnaire were identified and two groups were chosen: members of the community and real estate agents. The aim was to capture two different perspectives: one linked to demand (the changing needs of the community) and one of those directly operating in the real estate market (as mediators between demand and supply).

Both questionnaires were distributed using the Google Forms online tool. Most answers were structured as multiple choice in both questionnaires. Some open-ended questions were also included.

The community was interviewed through citizens' associations. A total of 248 associations operating in the metropolitan area of Naples were identified in the Campania region official register. The associations were contacted by email and social networks. A total of 
196 questionnaires (79\% of the associations identified) were completed over two months (September and October 2020).

The questionnaire was divided into six sections, for a total of 26 questions. After an introduction detailing the aims and objectives of the questionnaire, the first section was related to the respondents' data in order to understand the sample analysed. The second and the third sections aimed to understand the types and characteristics of each respondent's house and where they spent the lockdown. Section four aimed to understand the adequacy of the housing spaces to meet the needs of the community during the lockdown. During that period, homes became spaces for living, working and leisure activities. Section five aimed to understand how future demand for housing is changing based on the needs that emerged (and are still emerging) during the lockdown. The final section aimed to understand whether the respondents were planning to buy or rent a house and to investigate how (and if) this demand was changing compared to the pre-COVID-19 period as a result of living "within four walls".

The real estate agents were contacted directly by email and through the Italian Federation of Business Agents Mediators (FIMAA). The questionnaire was completed by 71 real estate agents operating in the metropolitan area of Naples over a period of two months (September and October 2020).

After a brief introduction describing the aims and objectives of the questionnaire, the respondents were presented with a section of 20 questions. The aim was to understand, from the perspective of the real estate agents, how the volume and prices for buying, selling and renting during the pre-, mid- and post-lockdown periods changed (and are continuing to change) in relation to the real estate market for residential use. Furthermore, considering the restrictions imposed due to the health emergency, if and how real estate agents continued to operate during the lockdown was investigated. Additional questions were posed to understand the type of housing required in order to investigate whether the particular and critical situation has impacted demand and thus the real estate market in general. Finally, the strategies that could be undertaken by real estate agents to overcome the crisis more quickly were investigated.

\section{Analysis of the Pre-COVID-19 Real Estate Market}

In order to identify the impacts of COVID-19 on the real estate market in Italy, in particular in the metropolitan area of Naples, a general framework of the sector before COVID-19 is presented.

\subsection{The Pre-COVID-19 Real Estate Market in Italy}

In recent years, the national real estate market has recorded an increase in buying and selling, in spite of the Italian economic crisis. In most Italian metropolitan cities, at the end of 2019, there was growth in terms of buying and selling, and in renting, with an increase in real estate buying through agencies. In 2019, the "brick" market recorded growth in buying $(+4 \%)$ and renting $(+3 \%)$, while prices dropped by $-2.77 \%$ compared to the previous year (2018) [21].

The Italian Revenue Agency makes available data relating to the number of normalised transactions (NNTs), which represent the number of normalised transactions of property units (by share of property being transacted) carried out in a given time span. Transactions are "calculated" for each property unit, taking into account the share of property sold. The year 2019 was a year of growth, with over 603,000 sales, a higher number than in 2009 (approximately 585,000 NNTs), that is, the first year following the global economic crisis of 2008. The national increase in NNTs in 2019 compared to the previous year was $+4.2 \%$ [22]. The sales trend was also reflected in the real estate market intensity index (MII) values, which represents the trend of the ratio between transaction and stock. As a national average, the MII increased from 1.69\% (2018) to 1.76\% (2019), highlighting growth, especially in the bigger cities: after Milan (the only city with an MII higher than 3\%) were Bologna, Turin, Florence and Rome. 
The pre-COVID-19 rental market registered good dynamism. From 2009 to 2019, rents almost returned to pre-financial-crisis levels (2008), reflecting the changes taking place in society: more people were deliberately choosing to rent due to greater flexibility or because they could not obtain credit [23]. In 2019, there was an increase in the percentage of rent for residential use compared to other reasons, such as work or study: from $57.0 \%$ (2018) to $64.7 \%$ (2019) [24].

Regarding property price trends, Italy behaves in an anomalous way compared to the rest of the European countries. In fact, as the Statistical Office of the European Union (Eurostat) highlighted, in contrast to other European countries where prices increased in the second quarter of 2019, prices fell in Italy $(-0.2 \%)$ [25]. In general, the data show that the price of houses in Italy has been steadily falling over the last five years, except for 2016. Within Italy, there are also significant differences between the north, where prices increased in 2019, and the centre and south, where they decreased. The decrease in real estate prices and more advantageous mortgages pushed people towards the buying choice; however, despite this, rental demand was high, especially among younger people, with $46.4 \%$ of tenants aged between 18 and 34. The most popular rented accommodation was the tworoom apartment (37.4\%), followed by the three-room apartment (32.8\%) [24].

\subsection{The Pre-COVID-19 Real Estate Market in the Metropolitan Area of Naples}

Italian Law no. 56 of 7 April 2014 (known as the Delrio Law) established the metropolitan city as "a large-area territorial institution", with the aim of encouraging the combination of municipal administrations, the simplification of local government and the ability for cities to adopt a driving role in national economic systems [26]. Metropolitan cities assume different characteristics according to different urban contexts, depending on variability in terms of spatial distribution, economic potential, social welfare issues and demographic trends.

The Metropolitan City of Naples (Campania region, in the south of Italy) (Figure 1) is among the 14 Italian metropolitan cities identified by the Delrio Law. It has approximately three million inhabitants and covers 1171 square kilometres. It is a complex territorial system, due to its heterogeneity and the presence of an important and unique cultural and natural heritage $[27,28]$. The Metropolitan City of Naples is headed by the Metropolitan Mayor and by the Metropolitan Council, and includes 92 municipalities; here we use the term "metropolitan area of Naples" to identify its territory and differentiate it from the administrative organisation.

Italy is considered to be divided into three main areas (the north, the centre and the south) and they are characterised by different economic rates of growth, wellbeing and health conditions, education levels, employment rates, redistributive actions of the government and local authorities, etc. [29,30]. The Metropolitan City of Naples is the biggest and most representative in southern Italy; for this reason, it has been chosen as the case study for this analysis.

Structural aspects and the worsening of the economic crisis have led to an uninterrupted increase in the gap between southern Italy and northern and central Italy in terms of employment over the last decade. According to the latest data of the Italian National Institute of Statistics (ISTAT), in 2013, only $40.2 \%$ of people aged between 20 and 64 were employed in the province of Naples, 3.3 percentage points less than in 2008 [29]. This level of employment is 5.4 points lower than in southern Italy and 19.6 points lower than the national average. Linked to the situation in the labour market, the economic wellbeing of households also shows problematic data. In the four-year period 2009-2012, the per capita disposable income of consumer households decreased by EUR 138, compared to a national average increase of EUR 28. In 2012, the per capita disposable income of consumer households in the province was EUR 12,314, higher than the regional value (EUR 11,932) but lower than in the south (EUR 12,775) and nationally (EUR 17,307). In addition to income inequalities, households are experiencing greater economic difficulties, resulting from the increase in bank non-performing loans and the high proportion of people living in households where no member works or receives a pension, both of which are higher 
than in other territorial contexts. In 2008, the Italian real estate market was also affected by the global financial crisis (considering the close relationship between residential real estate, the financial sector and the overall economy), seeing a sharp turnaround compared to the boom that began in 1998 .

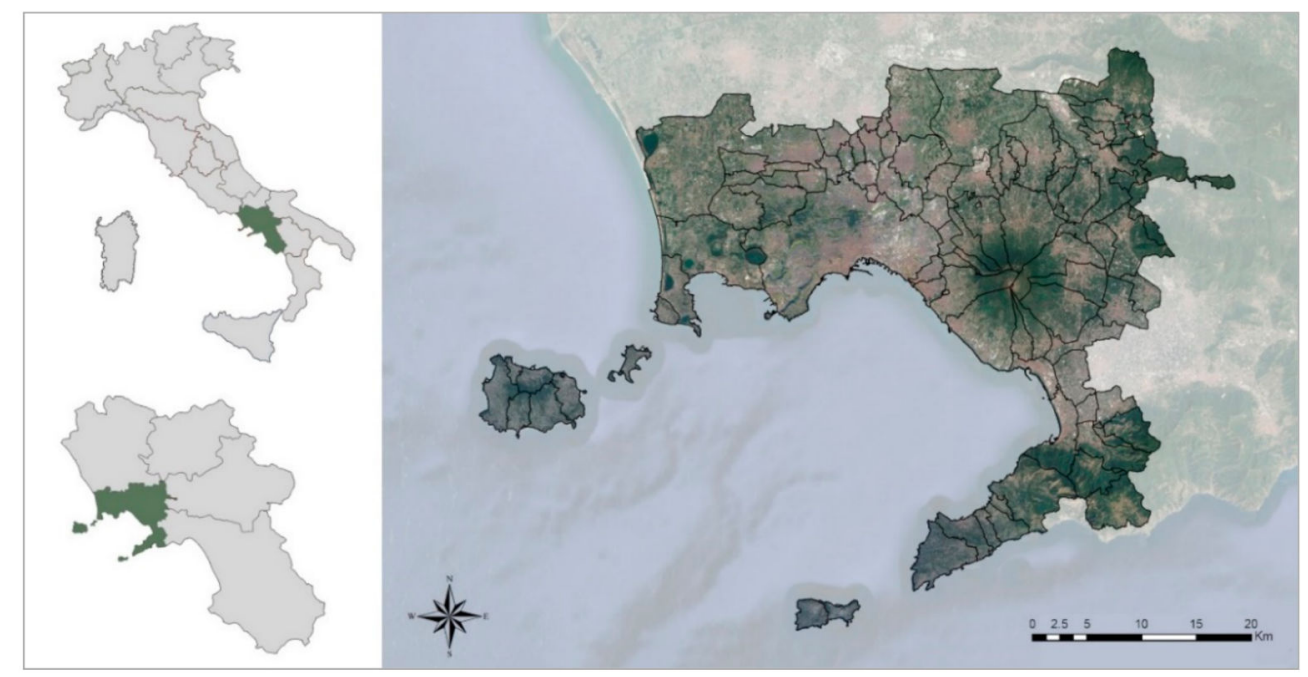

Figure 1. Territorial framework: Italy, Campania region, metropolitan area of Naples (based on Google Earth 2020).

Since 2008, the metropolitan area of Naples has operated in the context of great difficulty from an economic and financial perspective. This criticality has also been felt in the real estate market, which in recent years has shown signs of decline [18]; between 2009 and 2019, the house prices have suffered a strong decrease with peaks of $-50 \%$ in some municipalities [31]. This suggests that the effects of the 2008 financial crisis are still tangible. Therefore, the main actors and government institutions must be encouraged to promote strategies and interventions aimed at promoting the attractiveness of the area.

In order to identify trends in pre-COVID-19 market values, in this study, the metropolitan area of Naples is divided into nine macro-areas (Figure 2), including different municipalities [32].

Concerning the real estate stock of the metropolitan area of Naples, the last census by the Italian National Institute of Statistics reports that there are 128,976 empty housing units and 13,777 empty buildings [33]. These empty properties, mainly localised in the historic centre of the city and characterised by historical value, represent a great potential for future investments in the real estate market. Furthermore, in 2019, in the metropolitan area of Naples, there were over 61,853 properties advertised for sale and 28,353 for rent [34]. After years of decline, residential property sales increased towards the end of 2019 as result of falling prices [35]. The gap between the fall in prices and the increase in the number of sales is essentially due to the greater supply of properties compared to demand and, due to the continuing crisis, the supply has necessarily had to adapt to what buyers can afford. In addition, mortgage rates are also remaining at historic lows. As a result, demand for mortgages continues to grow, especially for first homes. The average price of an apartment for sale was approximately EUR 1870/sqm in 2019. The most popular property type for sale was the apartment, with 32,167 advertisements overall, followed by single-family houses (6956 advertisements). The most popular property type for rent was the apartment too, with 11,102 advertisements in total, followed by commercial premises (4776 advertisements) in 2019. The City of Naples published the highest number of real estate advertisements (38\%) compared to the other municipalities [36]. 


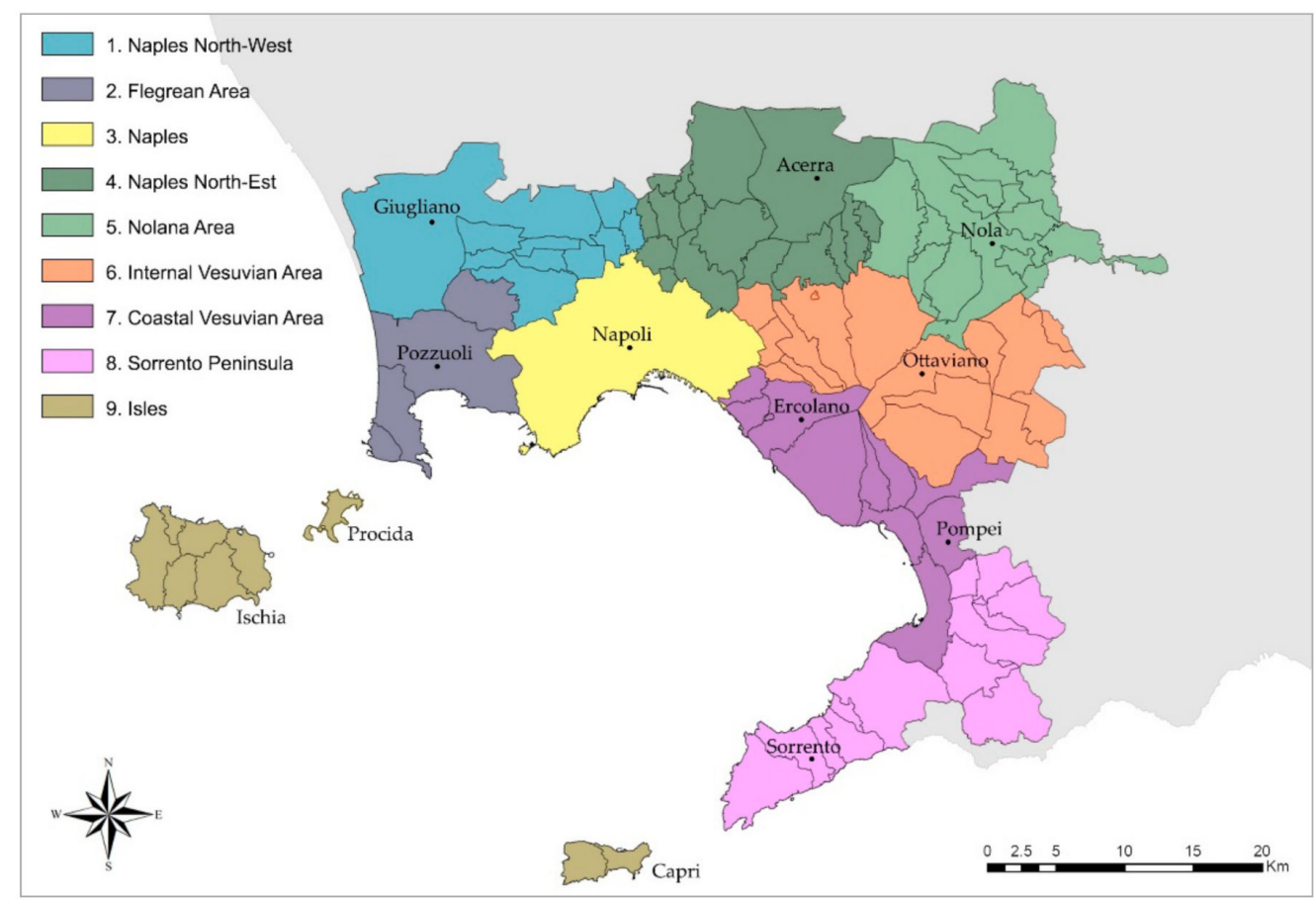

Figure 2. Real estate macro-areas in the territory of the metropolitan area of Naples.

As shown in Table 1, in the past 12 years, the metropolitan area of Naples recorded a $-23.73 \%$ reduction in market values for house sales. The year 2009 is taken as the initial reference year for the trend because it immediately followed the 2008 global financial crisis. In absolute value, the Isles record the highest prices in both 2009 and 2020, while the Nolana area had the lowest prices (Table 1). The most affected area in terms of percentage variation of prices was the Flegrean area, recording a drop in prices of $-39.76 \%[32,37,38]$. The least affected area was the Sorrento Peninsula, with a drop of $-16.35 \%$.

Table 1. Real estate values for the metropolitan area of Naples (EUR/sqm).

\begin{tabular}{cccccccccccccc}
\hline Macro-Areas & $\mathbf{2 0 0 9}$ & $\mathbf{2 0 1 0}$ & $\mathbf{2 0 1 1}$ & $\mathbf{2 0 1 2}$ & $\mathbf{2 0 1 3}$ & $\mathbf{2 0 1 4}$ & $\mathbf{2 0 1 5}$ & $\mathbf{2 0 1 6}$ & $\mathbf{2 0 1 7}$ & $\mathbf{2 0 1 8}$ & $\mathbf{2 0 1 9}$ & $\mathbf{2 0 2 0}$ & $\begin{array}{c}\text { Variation } \\
\mathbf{2 0 0 9 - 2 0 2 0}(\mathbf{\%})\end{array}$ \\
\hline Area 1 & 1530 & 1490 & 1580 & 1577 & 1461 & 1426 & 1332 & 1208 & 1191 & 1193 & 1203 & 1163 & -23.97 \\
\hline Area 2 & 2710 & 2720 & 2628 & 2393 & 2230 & 2070 & 1935 & 1883 & 1825 & 1825 & 1660 & 1633 & -39.76 \\
\hline Area 3 & 2924 & 3045 & 3056 & 2828 & 2731 & 2604 & 2535 & 2450 & 2381 & 2366 & 2145 & 2082 & -29.01 \\
\hline Area 4 & 1426 & 1504 & 1508 & 1488 & 1425 & 1377 & 1353 & 1276 & 1271 & 1259 & 1153 & 1134 & -20.51 \\
\hline Area 5 & 1089 & 1125 & 1149 & 1090 & 1053 & 1016 & 1017 & 979 & 911 & 911 & 963 & 851 & -21.86 \\
\hline Area 6 & 1494 & 1500 & 1865 & 1421 & 1344 & 1276 & 1264 & 1274 & 1231 & 1245 & 1179 & 1087 & -27.22 \\
\hline Area 7 & 2049 & 2029 & 1925 & 1862 & 1840 & 1743 & 1701 & 1679 & 1622 & 1605 & 1665 & 1670 & -18.50 \\
\hline Area 8 & 3031 & 2962 & 2754 & 2633 & 2812 & 2717 & 2608 & 2505 & 2532 & 2520 & 2552 & 2535 & -16.35 \\
\hline Area 9 & 5260 & 4958 & 4630 & 4388 & 5072 & 4873 & 4473 & 4320 & 4122 & 4101 & 3941 & 3769 & -28.34 \\
\hline Metropolitan area & 2134 & 2111 & 2107 & 1961 & 2002 & 1921 & 1840 & 1775 & 1729 & 1724 & 1690 & 1628 & -23.73 \\
\hline
\end{tabular}


A series of maps was elaborated to understand market prices in the metropolitan area of Naples, using a geographic information system (GIS), in order to territorialise such data and graphically "read" the real estate dynamics (Figures 3 and 4). These maps are the result of the georeferencing of data related to residential market values of Table 1, showing in the present paper only the maps referring to two specific years: 2009 (following the 2008 financial crisis) and 2020 (the most recent full year). The values are organised into seven categories; these were decided using the Jenks natural breaks classification system [39] and successive manual adjustments to allow more defined classes. The resulting maps show that house prices recorded a decrease from 2009 to 2020, changing in colour in some areas from dark brown (higher market prices) to lighter brown (lower market prices).
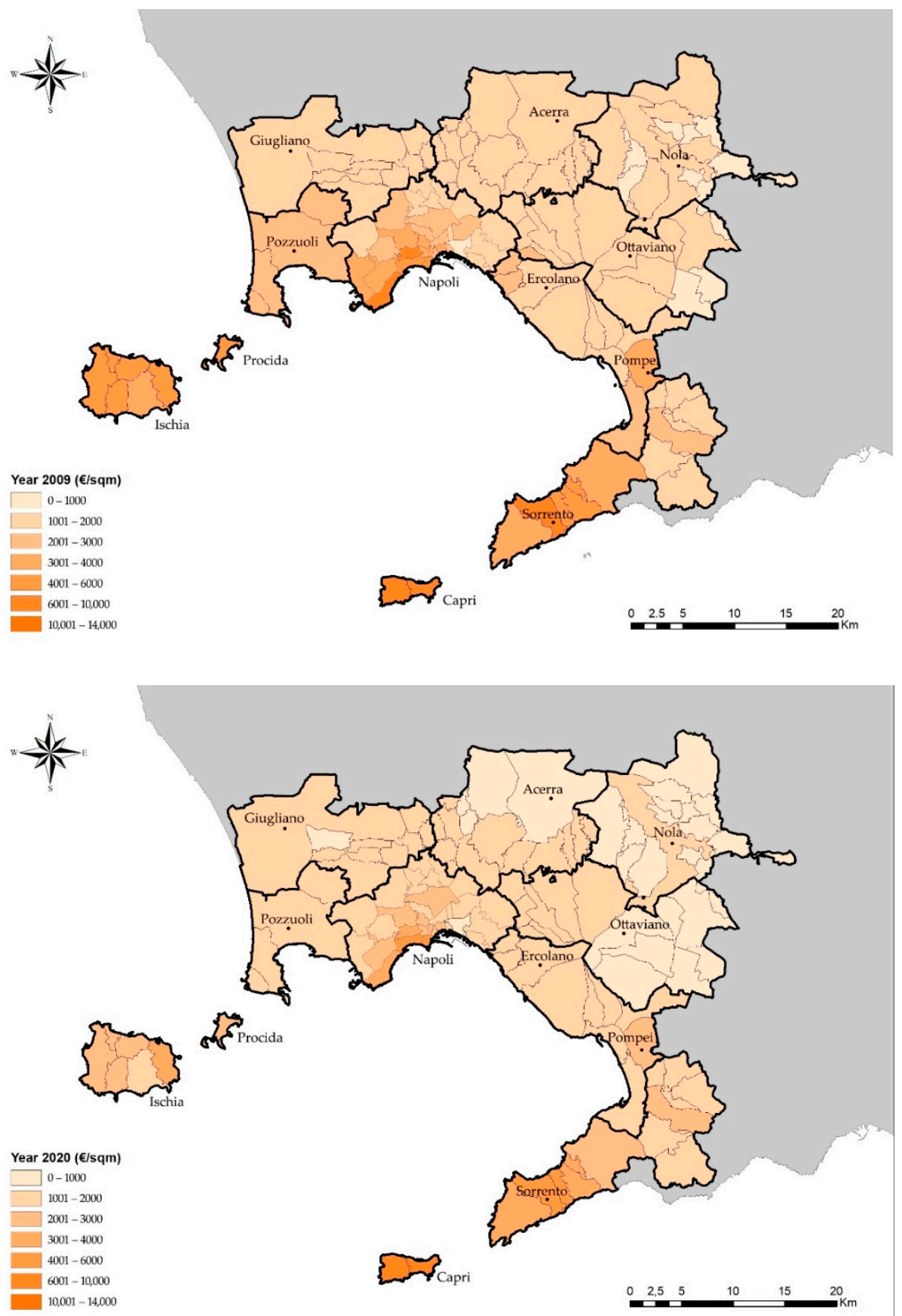

Figure 3. GIS maps of market values for the metropolitan area of Naples, for 2009 and 2020. 


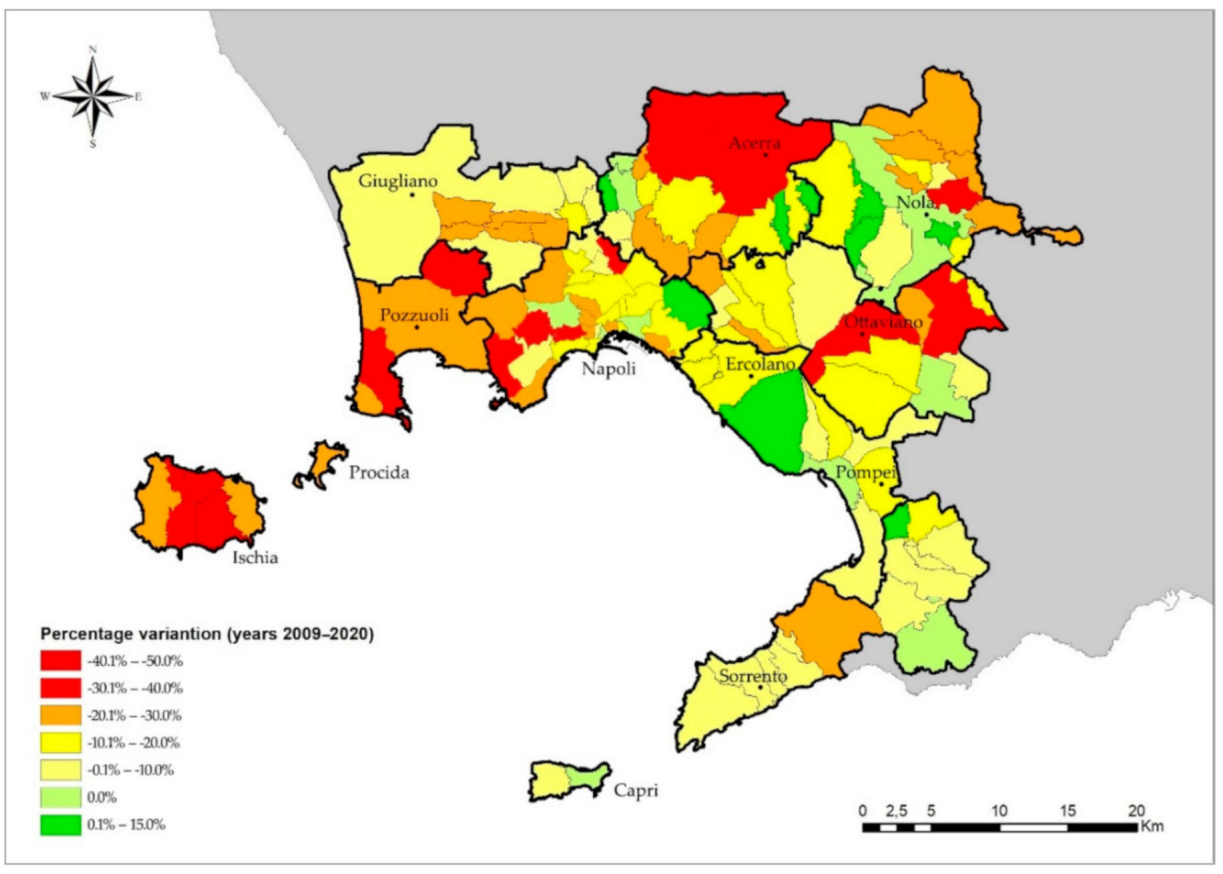

Figure 4. GIS maps of percentage variation of the market values for the metropolitan area of Naples, from 2009 to 2020.

The Figure 4 shows the percentage variation of the residential real estate prices from 2009 to 2020. It emerges that the prices mainly decrease in the identified time span in the whole metropolitan area of Naples, with peaks in reduction between $40 \%$ and $50 \%$ in some areas. There are a few areas where price stability or increases were observed (but never more than $15 \%$ ).

Focusing on the largest and most complex municipality (the City of Naples), the data relating to the number of normalised transactions (NNTs) in the residential sector, provided by the Italian Revenue Agency, show a decrease in sales of $-2.4 \%$, from 2018 to 2019, for a total of over 7400 exchanges [40]. Figure 5 shows the NNTs for Naples per square metre in 2019.

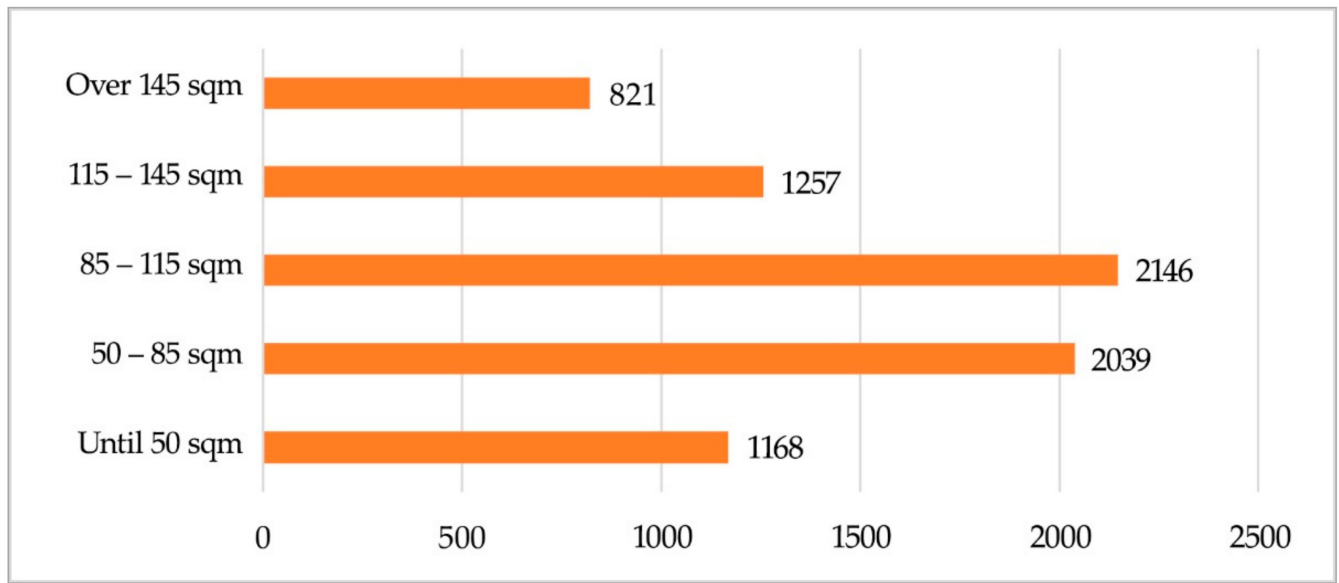

Figure 5. Number of normalised transactions (NNTs) for Naples divided by square metre.

In the past ten years, house prices in Naples have decreased by $-38 \%$, which is a worse trend than the national average of $-30.8 \%$. Contractions in central areas of the city were more contained for the same period, seeing a drop of $-24.9 \%$ [41]. Furthermore, in 2019, rentals saw an increase of $0.9 \%$ in the City of Naples. Reasons given for renting are related to weekly commuting to work (13.7\%) and study (3.3\%) (people who usually live in other cities 
but that during the week work/study and stay in Naples), and residential use (83\%) [24]. Most commuting is due to localisation of the main commercial and manufacturing activities in the metropolitan area of Naples.

\section{Forecasts for the Post-COVID-19 Real Estate Market in Italy}

The lockdown caused an economic and social crisis in Italy that, as highlighted earlier, will reverberate in the future real estate market. Several research institutions are attempting to outline future scenarios; however, the uncertain and unstable phenomena that Italy is experiencing make predictions difficult. Experts in the sector have engaged in interesting debates about possible future scenarios. Which investors in the "brick" market will suffer losses? Will residential stocks depreciate? With the recent lifestyle changes and subsequent requests for housing, will only part of the sector suffer a drop in demand? There are divergent positions in terms of the answers to these questions: some studies report a stationary market that has not yet suffered the negative influence of the lockdown imposed to tackle the health emergency, while others advance a more pessimistic evaluation, with a $20 \%$ reduction in buying and selling [42].

The Italian National Institute of Statistics (ISTAT) expects a decrease in GDP of $8.3 \%$ in 2020, and a partial recovery in 2021 [43]. The real estate market is confirmed as one of the few sectors in the Italian economy that the country could leverage to accelerate a restart [44]. For this reason, it is useful to investigate the outcomes of the health crisis and the possible recovery of the residential market.

\subsection{Forecasts for Post-COVID-19 Buying, Selling and Rental Market}

In Italy, investments in the "brick" market were the most profitable for citizens in 2019 [21]. If Italy had not suffered as a result of the pandemic, according to some forecasts, 2020 would have been an excellent year for buying properties at stable prices. Instead, a very complex phase emerged, slowing down the resilience of the real estate market, which, after the 2008 financial crisis, was beginning to recover.

The first post-health-crisis forecasts made by agencies and economists were negative: real estate is expected to have generated approximately EUR 105.8 billion in revenue by the end of 2020, down by 18.3\% from EUR 129.5 billion at the end of 2019 [45]; about 100,000 fewer homes will have been sold in 2020 compared to 603,000 units sold in 2019 [46]. This evaluation is based on the months of lockdown and it is still difficult to hypothesise how missed transactions can be recovered in the last months of the year. A rebound will be more probable in 2021, even if the variables that can be considered and which will affect market trends are several, from employment to the weight of public intervention, to investment inclinations of families and businesses [47].

A study by Gabetti and Patrigest (real estate operating companies) states that, "excluding situations of sudden lack of liquidity for households, those who wanted to buy a house continued to look for it" [48]. In crisis situations, Italian families' recourse is real estate investment. This could increase the market for second homes, considering that smart working leads to spending increasing amounts of time in holiday homes. In terms of rentals, the pandemic could cause various effects such as the lowering of rents, especially if the economic crisis affects people's income [23].

In order to investigate future trends in the real estate market, a forecasting model was set up to assess the impacts of the crisis. In particular, an econometric model could predict price trends as far ahead as 2025 by evaluating real estate trends after COVID19 [49]. This model analyses seven steps of crises of the last century, evaluating the social and economic variables and the ways in which these have changed (significantly or not, positively or negatively). This model was then transferred to the current pandemic emergency, and the parameters were adjusted based on this specific period. According to this ad hoc evaluation, real estate prices will fall in 2021, but a strong recovery will be expected over the next five years [50]. 


\subsection{Forecasts for Tax Incentives and Changes in Housing Demand}

Some forecasts show that tax incentives promoted by the Italian government, such as Eco-bonus (a tax incentive from the Italian government that provides a deduction rate of $110 \%$ of expenses incurred for specific energy-efficiency interventions until December 2021), Sisma-bonus (a tax incentive that the Italian government provides to those who renovate buildings by adopting anti-seismic measures) and subsidised first-home assets, could affect the recovery of the real estate market. According to a study by the Italian Department of Finance, in 2017 (last year available), almost 450,000 residential properties were bought as first homes, representing $82 \%$ of sales [51]; this is likely to increase due to contributions from Decree-law no. 23 of 8 April 2020 (so-called Liquidity Decree).

The Eco-bonus can be claimed to pay for thermal insulation, replacement of current systems with heat pumps, solar-photovoltaic systems and energy-efficiency interventions $[52,53]$. The Italian National Association of Builders (ANCE) estimates the future positive economic impacts of the Eco-bonus at EUR 21 billion, with an employment impact of 100,000 jobs [51]. ANCE also estimates an increase in GDB of $1.3 \%$, due to the effects produced on the economy by the building Eco-bonus, with an increase of $15-20 \%$.

Due to the lockdown, houses have considerable value in everyday life (not only market value) because the health emergency has led to changes in lifestyle and demand for real estate [54]. In fact, a new way of conceiving spaces has begun to emerge. Terraces and outdoor spaces in general will be indispensable; spaces for smart working and video conferencing, spacious lounges and larger living rooms will be also required [55]. The demand for suburban areas close to big cities and hinterlands could increase because it is easier to find features such as space and larger rooms at more advantageous prices in such areas. The market for second homes will be strong in some areas of Italy, as buyers are looking to improve their wellbeing, as well as clean air and unspoiled nature [56].

Nuveen Real Estate (a company active in investment management worldwide) uses the term "stuffocation" to indicate a trend emerging among consumers: "living better with less" [57]. The lockdown has forced citizens into more rigid lifestyles and, consequently, enabled them to review their purchasing behaviour and begin to make more informed choices.

\section{The Real Estate Market in Italy in the Post-Lockdown Phase}

Trends in the post-pandemic real estate market were analysed in order to understand the impacts the pandemic has had to date. Data were collected by real estate research agencies, including the Real Estate Observatory of the Italian Revenue Agency, real estate companies, sector experts and economists. The data refer to the first semester of 2020 [58].

The first quarter of 2020 was the period in which the health emergency began to manifest. All reported data do not yet fully capture the economic effects of COVID-19 on the real estate market; they will be entirely assessable in the coming months, interrupting the growth phase from 2014.

\subsection{Post-Lockdown Buying, Selling and Rental Market}

Lockdown, social distancing and the impossibility of meeting in person have undoubtedly affected the processes of buying, selling and renting. However, according to the survey by the Italian Federation of Professional Real Estate Agents [54], after a period of rest, the market is showing signs of recovery. Many real estate agencies have "made a virtue out of necessity", transforming limitations into opportunities to implement and improve virtual visit systems that have made it possible to maintain such activities. According to an article published in IlSole24Ore (an important economic newspaper), for example, some Italian real estate agency groups gained a market share of $20-30 \%$ due to the opportunities presented over the periods discussed [59].

In the first quarter of 2020, according to the Italian Revenue Agency, 117,047 residential transactions were recorded, a drop of $-15.5 \%$ compared to the same period in 2019 [58]. The available data revealed a temporary decline due to the reduced possibility of complet- 
ing deeds during the lockdown [60]. In the second quarter of 2020, the residential market became stationary compared to the same period in 2019 [61]. For this reason, despite the negative impact of the health crisis, the end of the lockdown marked the restarting of the real estate market, demonstrating that COVID-19 did not lead to Italians becoming unwilling to buy homes [62].

From March to June 2020, sales were related to purchases of first homes (77\%), investment (17.5\%) and holiday homes (5.5\%) [62]. Among the cities that suffered decreases in numbers of sales in the first quarter of 2020 were Naples $(-19.5 \%)$, Bari $(-19.5 \%)$, Milan $(-19.3 \%)$ and Genoa $(-19.2 \%)$. The least significant decline was seen in Bologna $(-6.4 \%)[63]$.

In terms of renting, there were downward trends in prices. Many tourist properties were transformed into residential homes through transitional contracts. The most relevant data relate to the mobility of university students and off-site workers, for whom rent demand dropped drastically during the lockdown. This was due to extensions for smart working and e-learning [64].

In Italy, the availability of rooms compared to 2019 more than doubled $(+149 \%)$. Milan had the highest availability of rooms $(+290 \%)$, followed by Bologna $(+270 \%)$. Supply almost tripled in Padua $(+180 \%)$ and Florence $(+175 \%)$ and doubled in Turin $(+108 \%)$, Rome (+130\%) and Naples (+100\%) [64]. However, COVID-19 did not change preferences for the type of houses that people searched for. A specific study recorded an increase of $8 \%$ (compared to 2019) in searches for one- or two-room apartments because people did not want to share spaces due to the risk of infection. It also found that $43 \%$ of owners were willing to reduce rent prices, in order to keep the possibility of renting their properties in medium-sized university cities such as Pavia, Pisa, Siena and Trieste. Owners of properties in the major cities were possibly waiting to see the outcomes of e-learning and university enrolment. In Rome, Milan and Naples in particular, prices maintained their usual levels [65].

The short-term rental market after the lockdown marked a boom in summer requests. During the 2020 summer period, there was a small increase in short rents by people who wanted to book holidays after being locked in their homes for months, feeling the need to "escape". Booking methods also changed (with mainly last-minute bookings) and booking periods were reduced to a few days. Booking.com recorded $40 \%$ of total reservations for the non-hotel sector compared to $34 \%$ in 2019. Some owners rented out their properties for short periods in order to renovate their first homes to take advantage of government incentives [66].

An increase in rental demand, instead, came from those who would not be able to access credit due to the difficult economic conditions [67].

\subsection{Changes in Housing Demand, Incentives and New Research Technologies}

After the lockdown, housing demand changed, with the requirement for outdoor spaces increasing. Property size became more important, and houses were required to be multifunctional, with modular spaces. Smart working requires suitable places to work in domestic spaces, and there was a growth in demand for specific spaces in the properties, such as garages, gyms and common areas [68].

The most requested house type after the lockdown was the three-room apartment, located close to essential services such as the metro, buses, supermarkets, pharmacies and food shops, equipped with terraces and balconies or private green areas and spaces for smart working [61]. Semi-central and peripheral areas were re-evaluated [68]. Furthermore, requests for second homes increased as result of the lockdown period. Some people were able to "escape" to their second homes before the "stay at home" measures were implemented, spending their lockdown there [7]. Moreover, the recorded cheaper prices pushed people to search for vacation homes, as confirmed by a study published in the LaRepubblica newspaper, which, from January to September 2020, recorded an increase in 
purchases of this house type from $5.9 \%$ to $6.5 \%$ of total house purchases compared to the same period in 2019 [69].

COVID-19 has significantly reduced economic activity compared to 2019. Currently, future prospects are still affected by uncertainty as the government continues to launch restrictive measures in terms of movement and production activities to limit the spread of the virus [70]. This has had an impact on the household credit market. It is essential to understand how citizens can access credit in order to purchase houses. Mortgage applications decreased in the first quarter of 2020. In April, the lowest number of mortgage applications was recorded in the year 2020, while in the second half of May there was a slow recovery. The rates are currently at historic lows, and the interest rate swap (the benchmark for the fixed rate at 30 years) is zero, which means that it is possible to activate a long-term loan at an interest rate of $1 \%$ [71].

In Italy, there is a high percentage of obsolete properties to which Decree-law no. 34 of 19 May 2020 Relaunch Decree (a legislative measure by the Italian government to face the health emergency by adopting measures on health, support for jobs and the economy, as well as social policies linked to the COVID-19 crisis) can be applied, or the $110 \%$ Eco-bonus or Sisma-bonus for energy requalification and seismic consolidation of real estate assets. This would help make real estate attractive again, increasing market value, by facilitating access to incentives [72]. According to the Italian Centre for Social Economic Market Research for Construction and the Territory, in the first three months of 2020, EUR 3 million were invested in these bonuses [73].

After the lockdown, more people used real estate agencies in their search for homes, to make investments or to obtain more comfortable and spacious houses [59]. The relaunch of the real estate agencies took place in new ways, with the use of digital technology such as virtual tours and online consultancies [2,74]. Using these tools, it is easier to stipulate a contract in order to reduce the impacts of the lockdown. According to a survey carried out from 4 May 2020 (the first day of reopening), demand for visits to properties for both purchase and rent increased, as well as requests to conclude transactions that had been interrupted during the lockdown [72]. After a period of rest, therefore, the first signs of recovery began to be seen.

\section{Results of the Questionnaires}

The results of both questionnaires have been analysed in order to understand how the real estate market has been changing due to COVID-19, by means of graphs and cross-tabulation analysis.

\subsection{Results of the Community Questionnaire}

The sample interviewed was heterogeneous in terms of both age and jobs, as shown in Figure 6.

The first part of the questionnaire showed the type and characteristics of the houses in which each respondent lives. From the questions about type, it emerged that $73.4 \%$ of the respondents live in apartment buildings. The remaining percentage live in "other types" (single-family house, semi-detached house, etc.). Moreover, most of the respondents are owners $(83.5 \%)$ of dwellings in central (49\%) or semi-central (25\%) areas.

Through the questionnaire, the presence (or lack) of outdoor private spaces was investigated. From the answers (each respondent could give more than one answer), it emerged that only $9.7 \%$ live in flats without private outdoor spaces; $67.3 \%$ live in flats with balconies; $28.6 \%$ have gardens; $8.7 \%$ have porticos; $7.1 \%$ have loggias and $3.6 \%$ have terraces (Figure 7). 


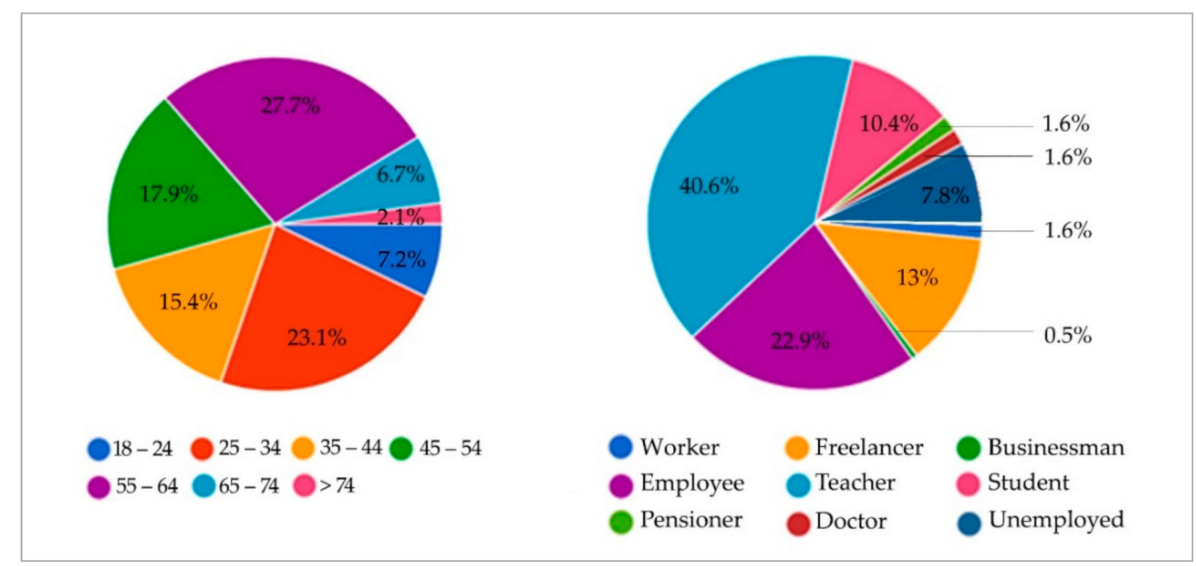

Figure 6. Ages and jobs of the respondents.

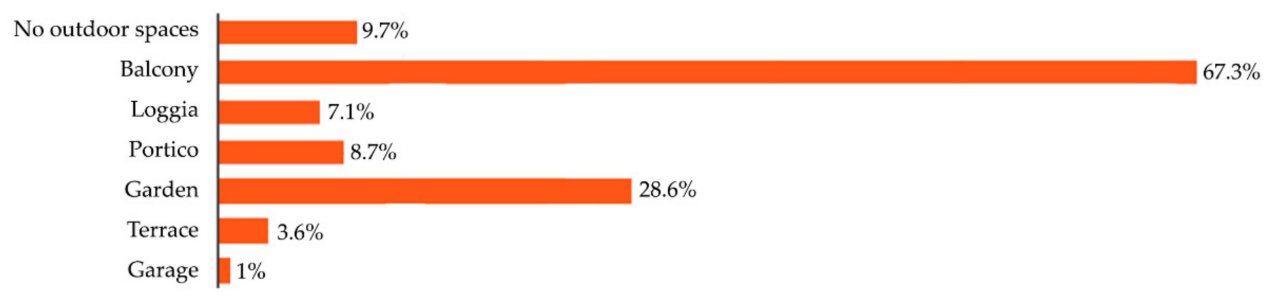

Figure 7. Presence of private outdoor spaces.

Most of the apartment blocks of the people interviewed have shared spaces (69\%), but only $17.9 \%$ of the respondents use them. The mild climate that characterises the south of the Italian peninsula, including Naples, would allow for the use of shared outdoor spaces. However, the amount of such spaces in the metropolitan area of Naples is reduced because over the years, the major Italian cities have been built according to plans that foresaw a very dense building fabric, to the detriment of such spaces. The outdoor places of sociability therefore remain predominantly public, such as squares, public parks, etc., rather than shared private spaces. However, there are shared indoor spaces in buildings which, as the survey shows, are not used enough by residents.

The section on the adequacy (or inadequacy) of housing spaces to adapt to changing needs and requirements highlights that $68 \%$ of the respondents believe that their houses were adequate to meet their needs since the beginning of the COVID-19 pandemic, whereas $6.2 \%$ are not satisfied and $21.1 \%$ are partially satisfied.

These data were cross-referenced (Figure 8) with data on the number of rooms in each respondent's house (abscissa on the graph) and their perceived adequacy to meet their needs during the lockdown period. The ordinate on the graph represents the number of respondents who expressed their perception of adequacy.

Considering the prevalence of apartment buildings in the metropolitan area of Naples, most of the respondents live in this type of housing. The other types, which represent a minority, have been grouped under "other types".

The "other types" are mainly large properties being mostly, as the cross-tabulation analysis shows (Figure 9), composed of four or five rooms. Flats, on the other hand, vary in size. However, most of the interviewees living in apartments have a three- to five-room house. 


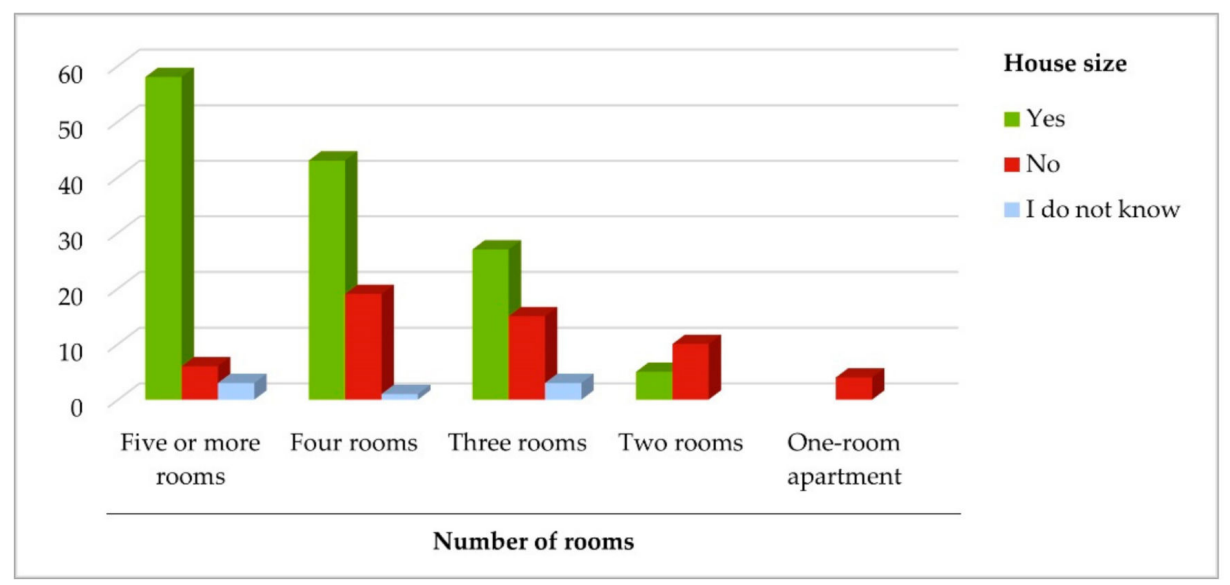

Figure 8. Relationship between number of rooms and house size.

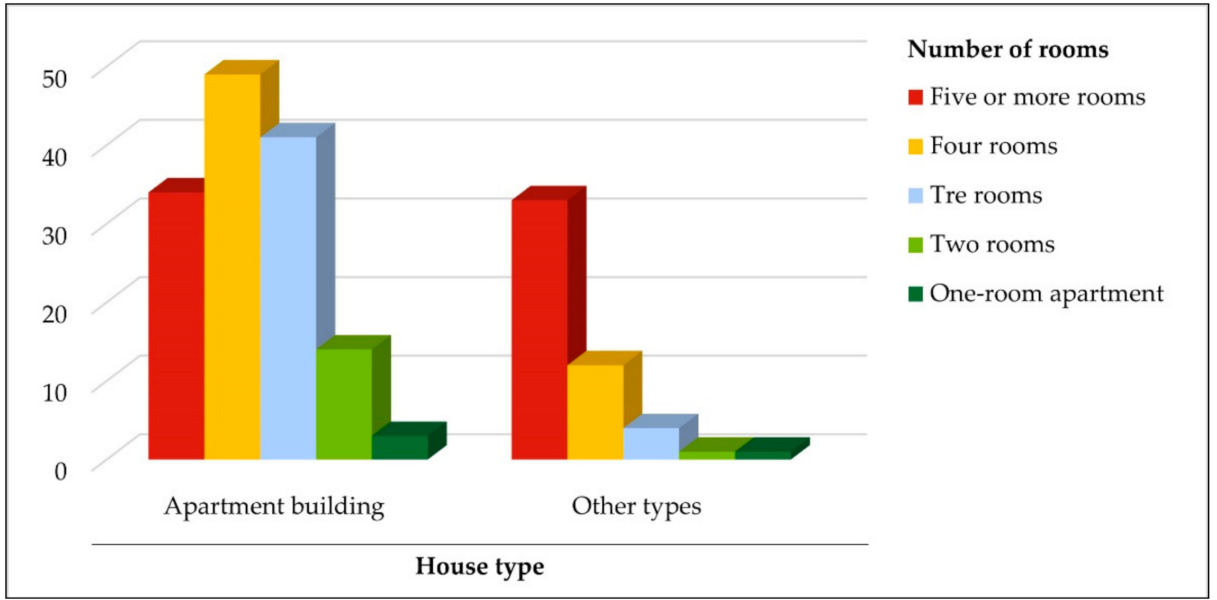

Figure 9. Relationship between house type and number of rooms.

As Figure 10 on the relationship between house type and private spaces shows, most apartments (75\%) are equipped with balconies, while the "other types" are mainly characterised by the presence of a garden (63\%). The metropolitan area of Naples and, in particular, the city of Naples, is characterised by a dense urban fabric in which the apartment building type prevails; the latter, due to its conformation, reduces the availability of outdoor spaces such as gardens, porticoes, etc.

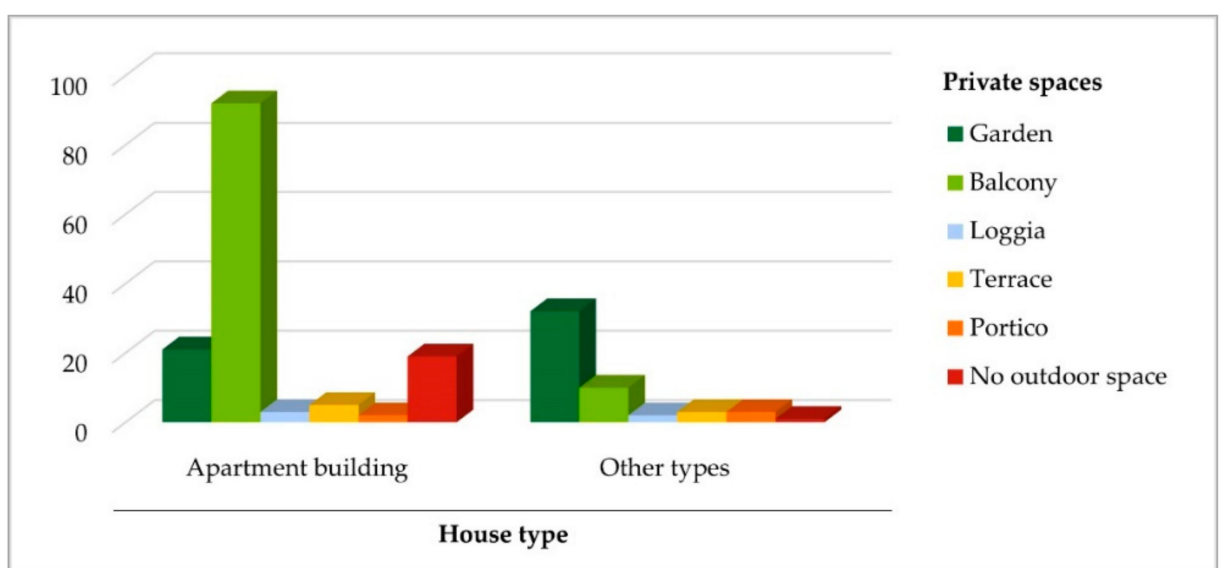

Figure 10. Relationship between house type and private spaces. 
As the respondents had to spend most of the day at home during the lockdown (going outside was only allowed in special cases), the spaces that were missed the most were outdoor spaces (terraces, gardens, etc.), $52 \%$ of the respondents felt this lack.

The data on housing type were related to the data on the spaces that the respondents had missed the most during the lockdown (Figure 11). This cross-tabulation analysis shows that the number of people living in apartment buildings who missed outdoor spaces was greater than those living in "other types" (semi-detached houses and single-family houses). Although representing a smaller percentage, those living in apartment buildings felt the lack of spaces in which to spend free time and work, while a small percentage of the sample interviewed did not feel the lack of additional spaces. Those living in "other types" did not feel a great lack of particular spaces.

Probably, in this period of "forced isolation" within the home, there is a greater need for spaces where there is more interaction with other family members, such as open spaces where activities and leisure time can be shared. However, this does not exclude the need for a personal space in which to maintain one's own privacy (for example to focus on work or to make online calls). A balance between having spaces for privacy and spaces for sharing would be desirable.

Houses during the lockdown became places to sleep, eat, work and engage in leisure activities, thereby satisfying several functions. For $68.7 \%$ of the respondents, however, the sizes of their homes were adequate, despite the increase in the number of activities carried out in them. However, $33.1 \%$ of the respondents felt that the spaces used for leisure time were not adequate. On the other hand, $23.4 \%$ felt that there was a lack of adequate spaces to use as a workstation. Only $10 \%$ felt no need for additional spaces other than the space in which they live.

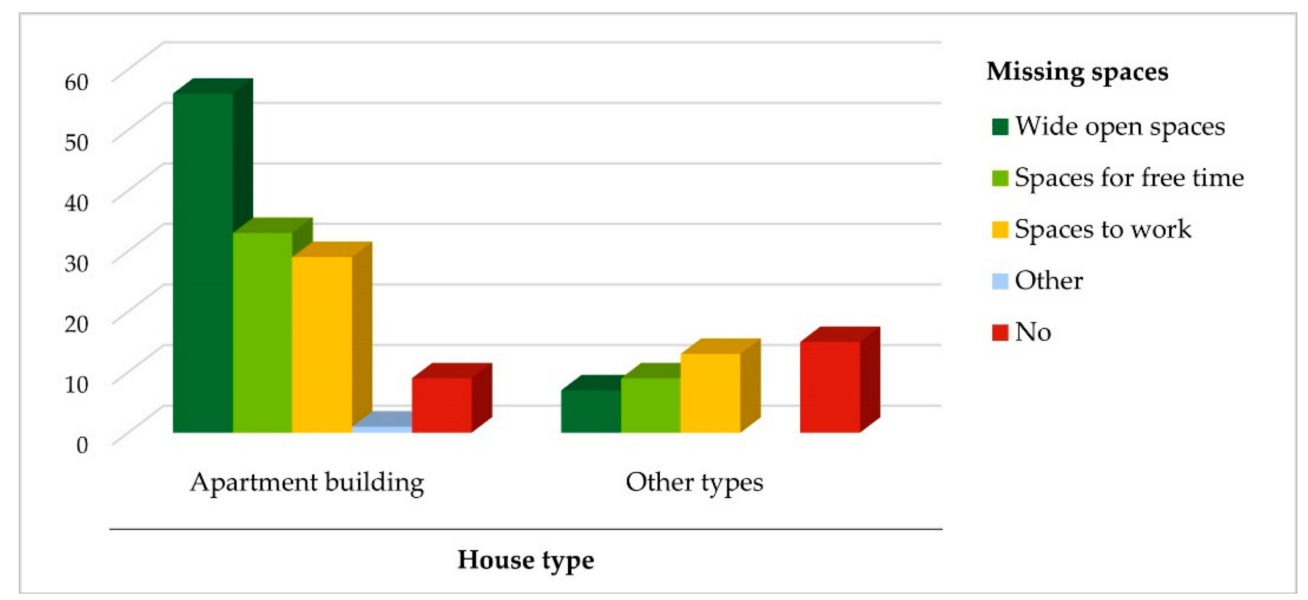

Figure 11. Relationship between house type and missing space.

Data relating to the number of household members were intersected with data relating to the perception of adequacy (or inadequacy) of the houses. The sample was composed of single people in a household $(7.7 \%)$, two people $(22.6 \%)$, three people $(22.1 \%)$, four people $(41.5 \%)$ and more than four people $(6.2 \%)$. Cross-tabulation analysis showed that, regardless of the number of people living together, the spaces available to the respondents were judged to be adequate to meet the changing living requirements during the lockdown period (Figure 12). 


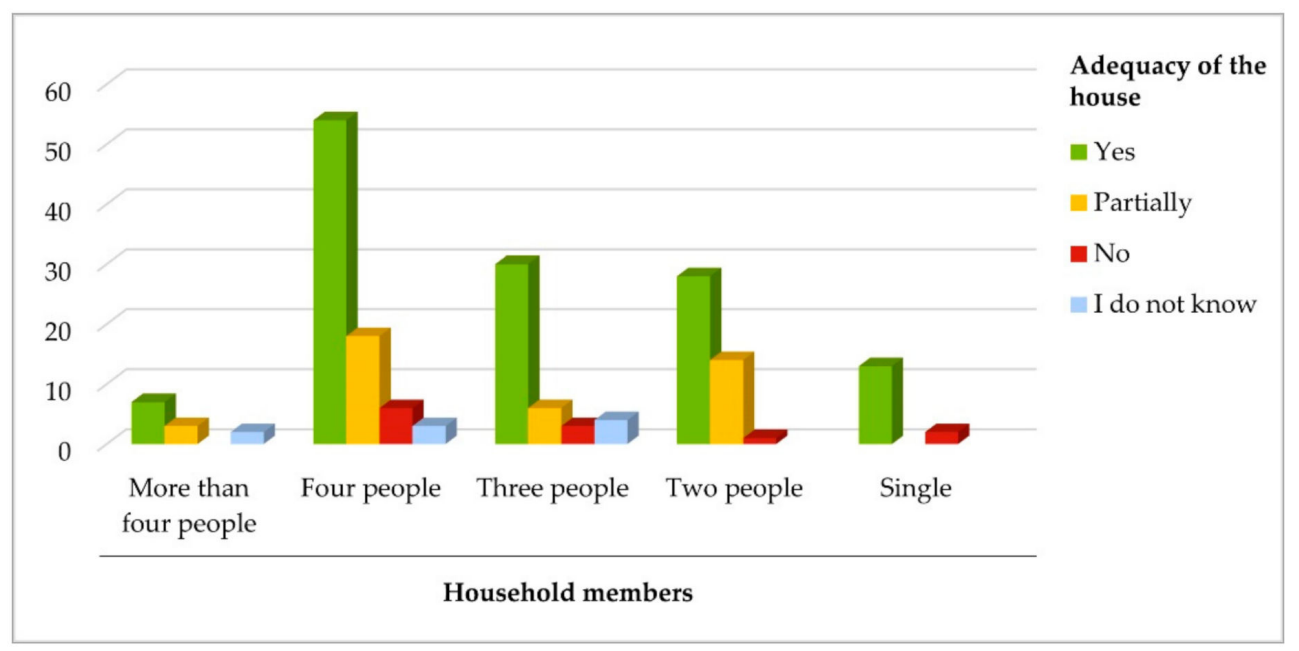

Figure 12. Relationship between household members and the adequacy of the house.

The analysis carried out in Figure 13 shows that the houses with the largest number of rooms were more adequate to satisfy the modified needs due to COVID-19. In fact, in these houses, the greater number of rooms allow for also accommodating the functions that during the lockdown had to be carried out within the domestic space. Furthermore, the percentage of people who did not consider their house adequate, regardless of its size, is very low. This is probably due to people's ability to adapt the available space to the different activities to be performed.

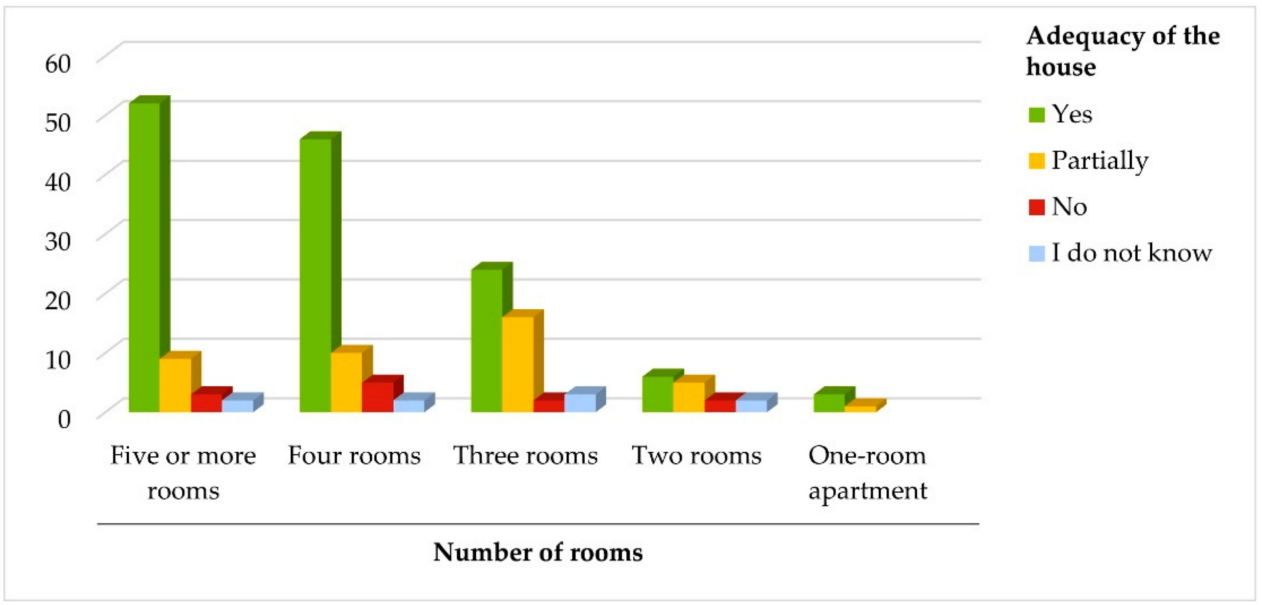

Figure 13. Relationship between number of rooms and the adequacy of the house.

The cross-tabulation analysis (Figure 14) relates the number of rooms to the age of the respondents, revealing that the two age groups of 45-54 and 55-64 have larger houses (and therefore more rooms), as they are most likely households (which in Italy rose later than in the rest of Europe) with more members than younger age groups.

Many people had to begin smart working during the lockdown (specifically, $79.9 \%$ of the respondents had to work away from their usual workplace and were therefore required to adapt their domestic spaces as workstations. In relation to the work/study spaces, $70.6 \%$ of the respondents (that is, almost all those who began smart working) considered their houses to be suitable for carrying out such activities remotely, and only $25.6 \%$ were dissatisfied. 


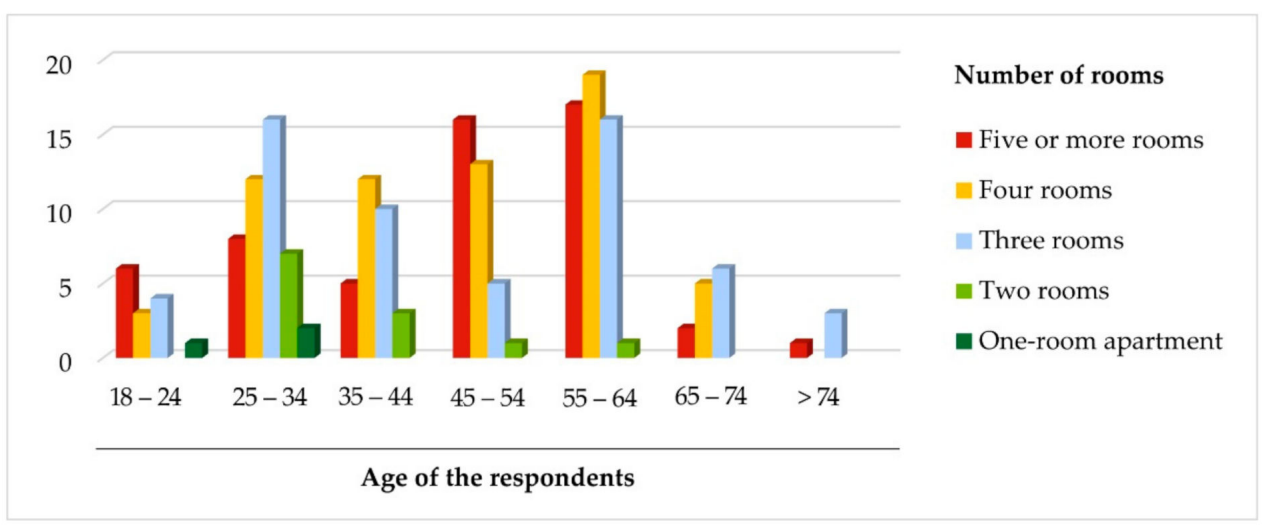

Figure 14. Relationship between the age of the respondents and the number of rooms.

During the lockdown, many people had to engage in indoor leisure activities that they would normally do outdoors around their houses. Therefore, the question was posed as to whether or not the domestic spaces were adequate to satisfy this necessity.

For outdoor activities, the answers were distributed more widely among the different options: $37.3 \%$ of the respondents did not engage in the activities that they would enjoy in the open, while $33.2 \%$ adapted their domestic spaces to include these activities. The remaining $29.5 \%$ did not usually engage in outdoor activities and therefore did not need to adapt their habits or their domestic spaces.

The analysis in Figure 15 highlights that both dwellers in apartment buildings and in "other types" are evenly divided between those who were able to carry out activities that they usually do outdoors by adapting the domestic space and those who did not have the space to adapt to carrying out leisure activities during the lockdown. The results show a certain balance between the two types, although the flats have fewer flexible spaces.

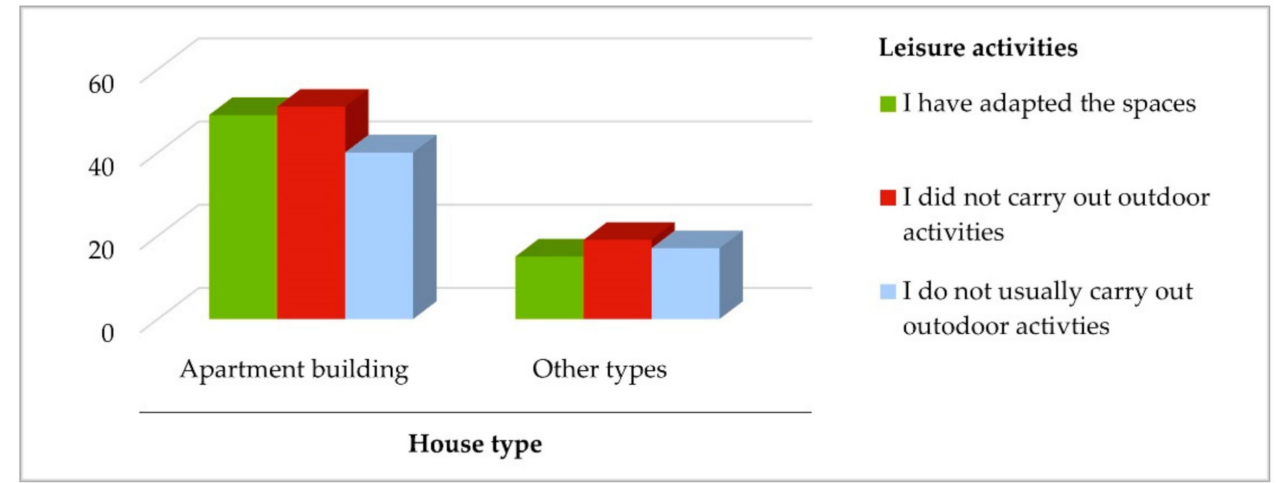

Figure 15. Relationship between house type and leisure activities.

In addition to the relationship between leisure activities and typology, the question was also whether the size of the house (in terms of the number of rooms) could influence the adaptability of the spaces for carrying out the above activities. The intersection of the data relating to the number of rooms and those relating to outdoor activities shows that those living in larger houses (five or more rooms) adapted their homes to carry out such activities. Among those living in small or medium-sized houses, there was a high percentage who gave up activities they would normally engage in outdoors (Figure 16). 


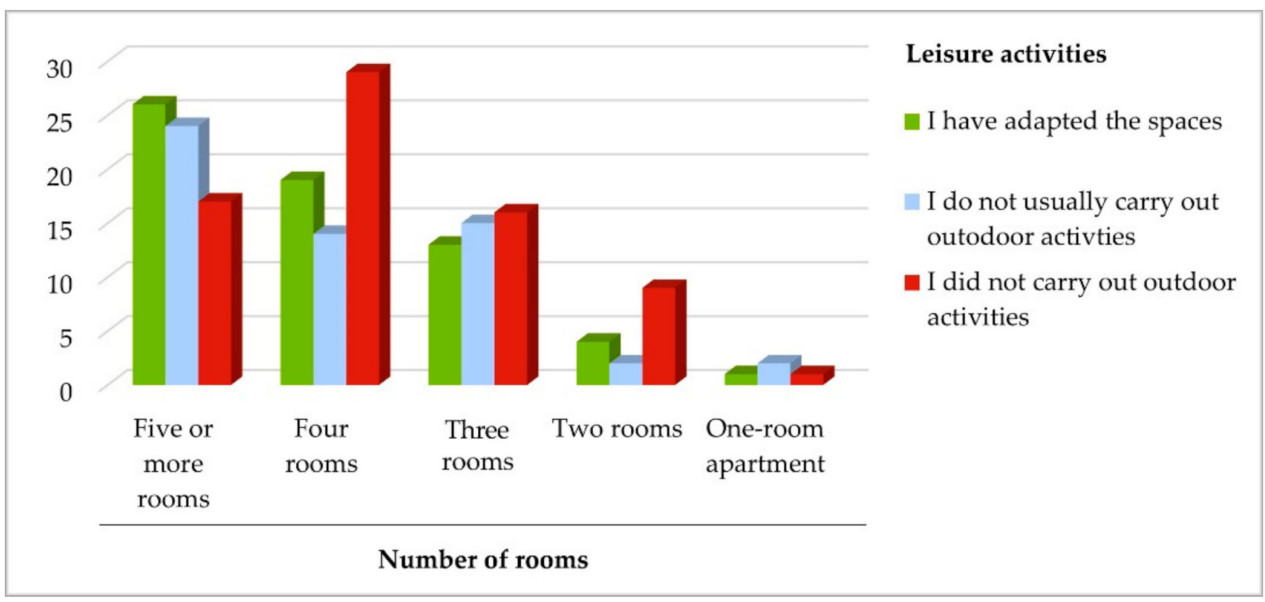

Figure 16. Relationship between number of rooms and leisure activities.

Concerning the characteristics of future dwellings (Figure 17), the results of the questionnaire show that $53.4 \%$ of the respondents would like more outdoor spaces, $39.8 \%$ would like better natural lighting (more sunlight) and $35.1 \%$ would like a better internet connection (an element that proved even more fundamental during isolation). Moreover, $33 \%$ of the respondents indicate that they would prefer better sound insulation in their spaces, $19.9 \%$ would like more separated living and sleeping areas (also better articulation of spaces for different activities carried out during the day, all of which took place within the domestic environment during the lockdown) and 9.4\% would like higher electrical power.

Smart working also leads to environmental considerations associated with workplace productivity. Indoor air quality, visual comfort, noise and thermal pollution can be the subject of greater attention and therefore future investments by owners (i.e., adopting windows with thermal imaging cameras, more efficient heating systems, etc.).

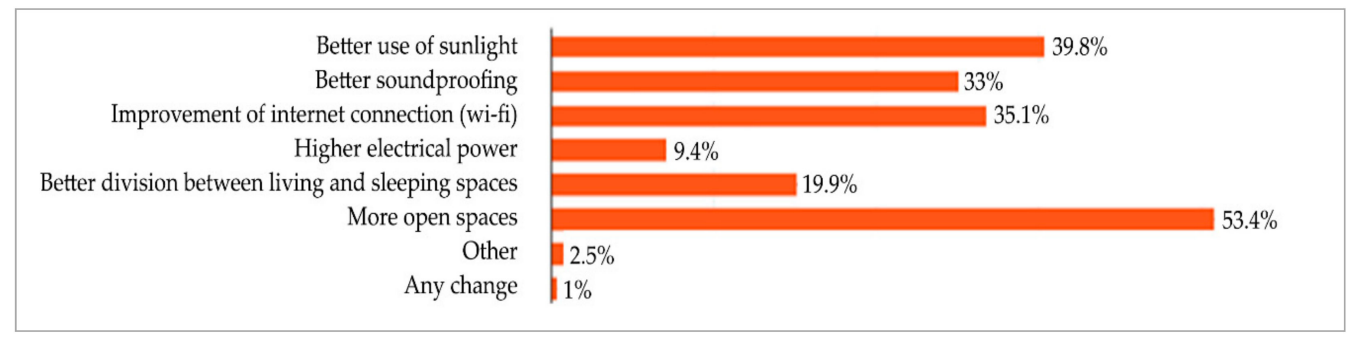

Figure 17. Desirable house characteristics for the post-COVID-19 period.

As highlighted above, in the lockdown period, digitalisation and technological equipment played an important role in contributing to improvements in the use of space and way of life (and keeping social interaction alive). Of all respondents, $52.8 \%$ feel that more advanced technology in the house would be an additional aid to traditional ways of working and studying, while $31.8 \%$ related technology in general as an aid to traditional ways of living.

According to some respondents, the contribution of technology will be significant. In fact, $16.4 \%$ of the respondents argue that it will completely change ways of working and studying, and $13.3 \%$ think it will completely change the way they live. Moreover, $21.5 \%$ believe that this "technological revolution" will be indispensable. On the other hand, $5.1 \%$ believe that COVID-19 has not affected the role technology plays in our lives, either in ways of working or ways of living in general. Finally, $5.1 \%$ answered "I don't know" to this question (Figure 18). This question was expected to be related to the ages of the respondents (the sample was heterogeneous, as shown in Figure 6) as there are groups of people who are more inclined to use technology and others who are less predisposed. 


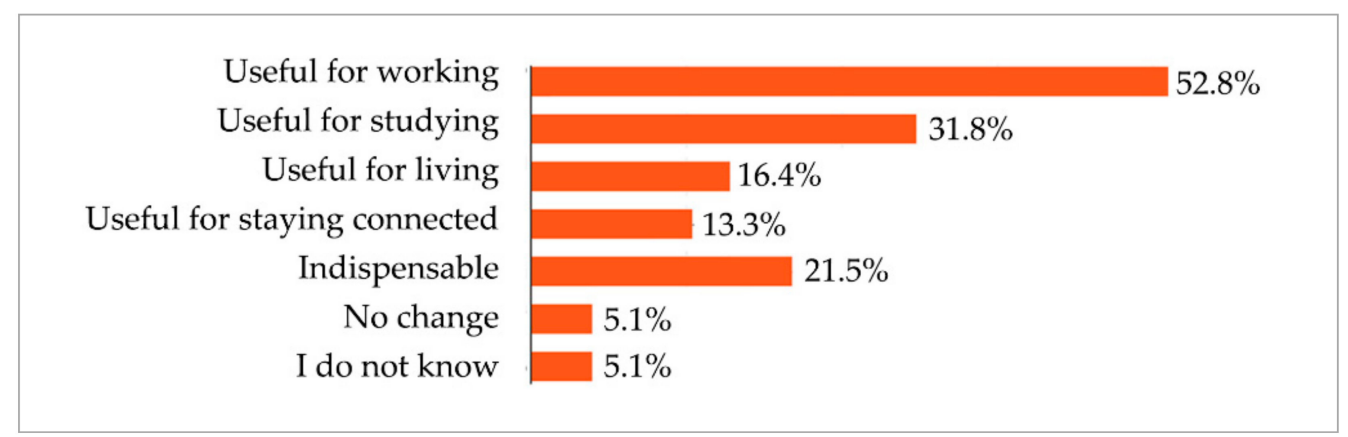

Figure 18. The role of advanced technology in houses in the post-COVID-19 period.

However, some questions were posed to understand preferences for the future characteristics of houses. Of all respondents, $75.9 \%$ have no intention of buying or renting a house in the short term. Only 21\% intend to buy a house in the short term, and 3.1\% intend to rent. On the other hand, $22.1 \%$ of the respondents intend to renovate their current flat. Most respondents state that, if they were to buy a house today, they would choose a central $(44.3 \%)$ or semi-central $(32 \%)$ location. Moreover, the highest demand is for flats with five $(28.4 \%)$, four $(33 \%)$ and three rooms $(30.9 \%)$. There is less demand for two-room (12\%) and one-room flats $(1.5 \%)$.

The data on the areas in which the respondents currently live were correlated with preferences concerning the areas in which they would look for a house if they were intending to purchase one. The analysis shows that those who live in central and semicentral areas today would remain where they are or, at most, would move to semi-central areas (Figure 19). On the other hand, those who currently live in semi-peripheral and peripheral areas would prefer to move to more central areas of the city. Those who live in the extra-urban areas would mostly prefer to stay where they are today.

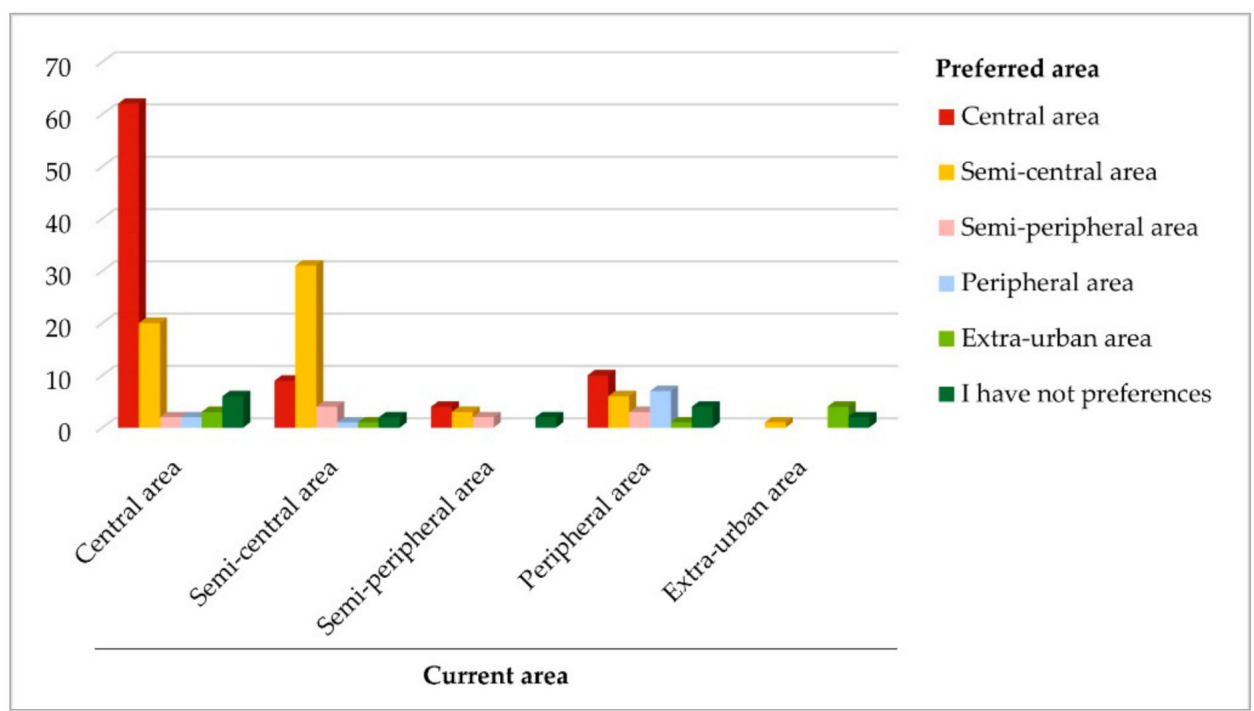

Figure 19. Relationship between current area and preferred area.

As shown in Figure 20,76.4\% of respondents would not choose to renounce their outdoor spaces such as terraces or gardens, and $41 \%$ would not give up a balcony, $30.8 \%$ would not give up a cellar, $41.3 \%$ would not give up a condominium parking space and $1.5 \%$ would prefer a private garage. Only 5.1\% would not give up condominium common areas. 


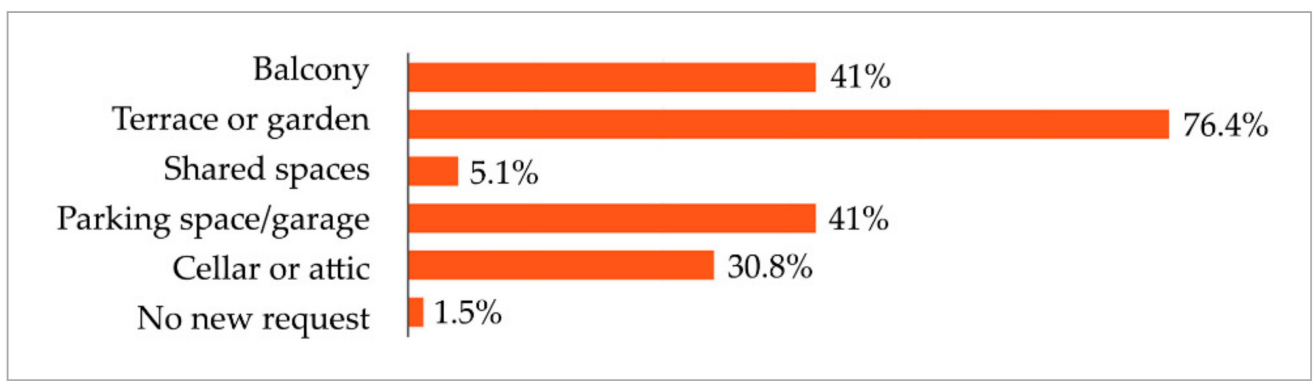

Figure 20. Non-renounceable spaces when buying a new house.

The questionnaire is used to find out which characteristics are most in demand when buying or renting a new house (Figure 21). Characteristics such as sunlight, sound insulation, thermal insulation, floor of the building and home automation were suggested. In addition, the questionnaire allows the respondents to indicate further suggestions. Natural light is fundamental for $85.1 \%$ of the respondents. Sound insulation (54.1\%) and thermal insulation $(56.2 \%)$ are also two important characteristics for most. Of the respondents, $34 \%$ prefer a high floor compared to $6.7 \%$ who prefer a low floor. Home automation, on the other hand, is chosen by $17.5 \%$. Other characteristics that emerge are aesthetic taste, proximity to essential services, presence of a private garden and presence of a green condominium park.

Smart working people use more heating to ensure a more comfortable working environment. Therefore, greater attention to thermal comfort and energy efficiency in houses will emerge as a result of this period of crisis. The growing worry about health also leads to a greater focus on own wellbeing, prioritising natural light and closeness to nature.

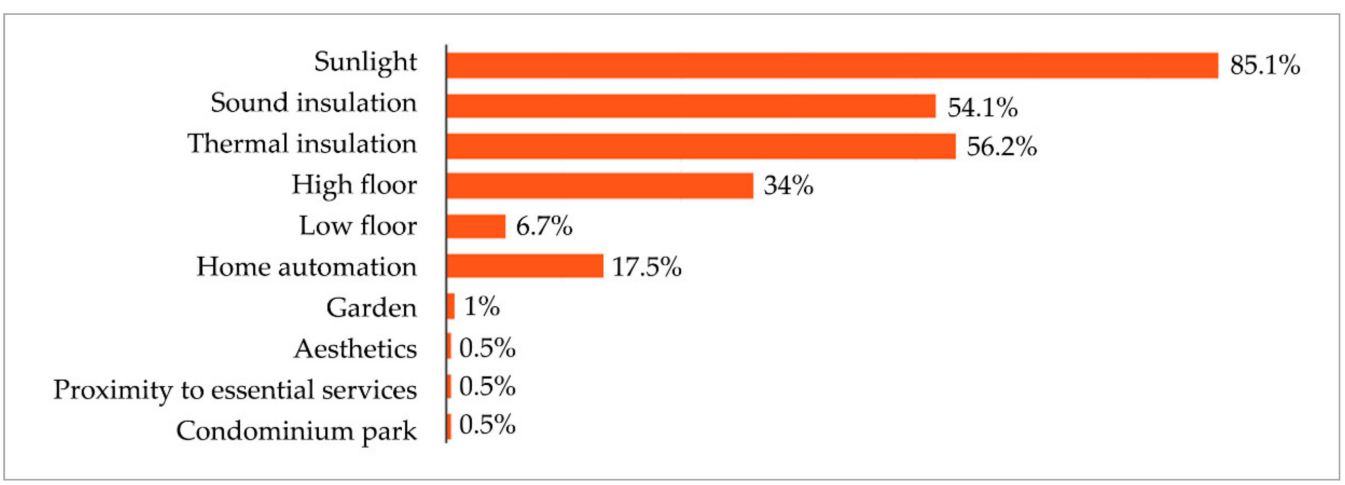

Figure 21. Non-renounceable characteristics when buying a new house.

Most of the respondents did no research when purchasing a new house (91.3\%), nor did they contact real estate agencies to buy, sell or rent (94.8\%). However, 50.3\% feel that the first visit to a flat in virtual mode rather than in person is useful as it reduces the time taken to buy, sell or rent. On the other hand, $40 \%$ feel that virtual visit makes it impossible to form the same perceptions that they would have in person. Of the respondents, 9.7\% answered "I don't know".

Among those who are planning to buy a house, the highest percentage refers to respondents between 25 and 34 years old (Figure 22). On the other hand, the highest percentage of those not looking for a house falls in the 55-64 age group, probably because they already have a stable housing situation. The only age group that stated they would like to rent a house is the 25-34 age group, as in Italy this is the age group in which people start working and therefore do not yet have enough money to buy a house, but feel the need to have their own independent living space. 


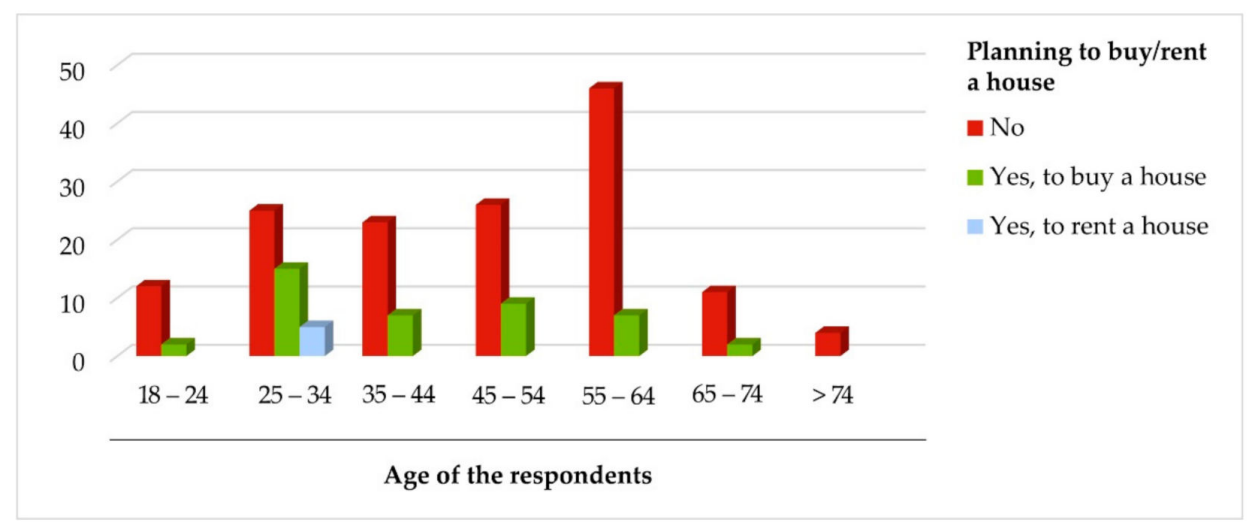

Figure 22. Planning to buy or rent a house by age group.

\subsection{Results of the Questionnaire Distributed to the Real Estate Agents}

The questionnaire was distributed to real estate agents operating throughout the metropolitan area of Naples. Of the sample, $72.1 \%$ operate in the City of Naples, while the remaining $27.9 \%$ operate in other municipalities of the metropolitan area of Naples.

According to the real estate agents, sale and rental prices in the residential sector remained fairly stable or were slightly down compared to the pre-lockdown period. In fact, as far as buying and selling prices were concerned, $58 \%$ of the agents believe that there had been no changes, while $37.7 \%$ believe that there had been a slight decrease. Only $2.9 \%$ believe that there had been a slight increase.

It is useful to understand the price variations in relation to territory. The crosstabulation shows that most of the agents observed no changes in price in the City of Naples compared to the pre-COVID-19 period (Figure 23). Only a small percentage reports an increase in prices. Additionally, in the metropolitan area Naples, most of the agents observe that there were no changes, and no-one observed slight increases.

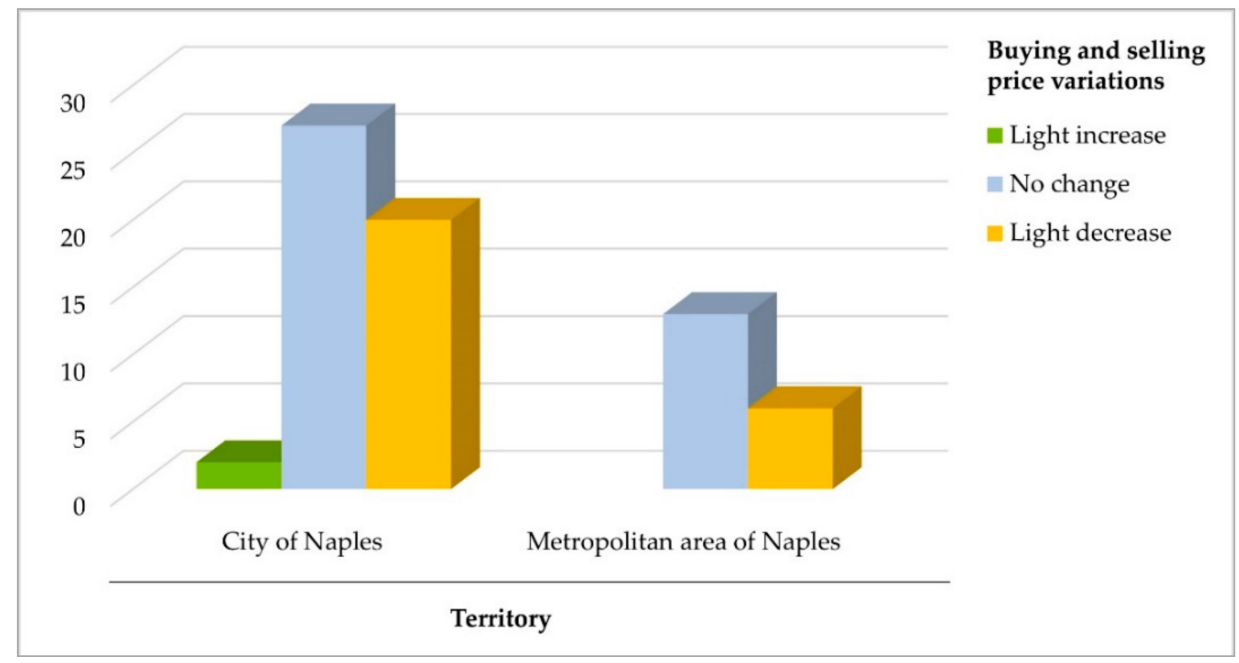

Figure 23. Relationship between territory and buying and selling price variations.

In terms of rental prices, $43.5 \%$ of agents state that there were no changes, whereas $39.1 \%$ state that prices were slightly down and $14.5 \%$ state that prices were slightly up.

Rental prices are also correlated with the distribution of the real estate agencies involved in the study in terms of territory. These data show that, in the City of Naples, the decrease in rental prices was significant, while in the metropolitan area, prices were more stable (Figure 24). 


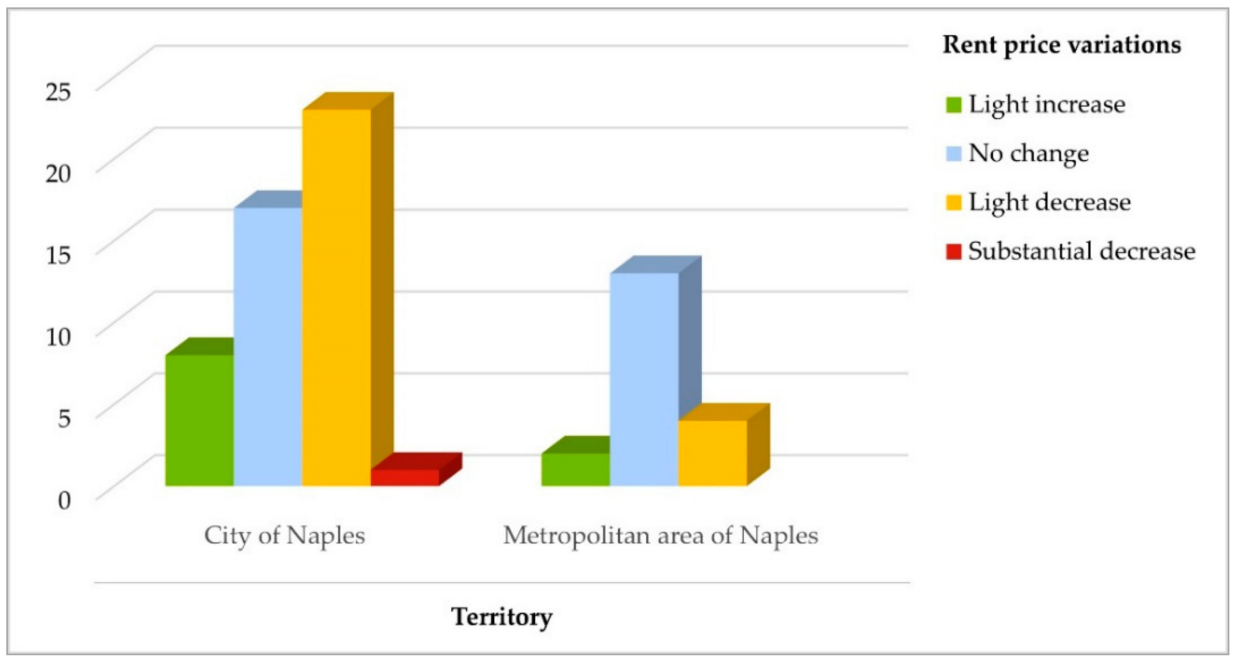

Figure 24. Relationship between territory and rent price variations.

In terms of the number of requests to buy and sell in the pre-lockdown period, $38.2 \%$ of the agents state that there was a slight increase, 33.8\% state that it appeared to be stationary and $23.5 \%$ state that there was a substantial increase. In the lockdown period, on the other hand, this number decreased substantially according to $34.8 \%$ of the agents, remained stationary for $29 \%$, decreased slightly for $17.4 \%$, increased slightly for $15.9 \%$ and decreased substantially for only $2.9 \%$. On the other hand, the number of requests to buy and sell compared to the pre-lockdown period has not changed according to $35.3 \%$ of the agents, it is slightly down for $27.9 \%$, substantially up for $8.8 \%$ and substantially down for $4.4 \%$.

In addition to price trends, the spatial distribution of the volume of sales and rents has been also analysed. The City of Naples, according to most of the respondent agents who operate there, did not record substantial changes, or, at the least, the number of purchases and sales saw only a slight decrease. The metropolitan area performed similarly, but with less of a percentage difference between those reporting no change and those who observed a slight decrease (Figure 25).

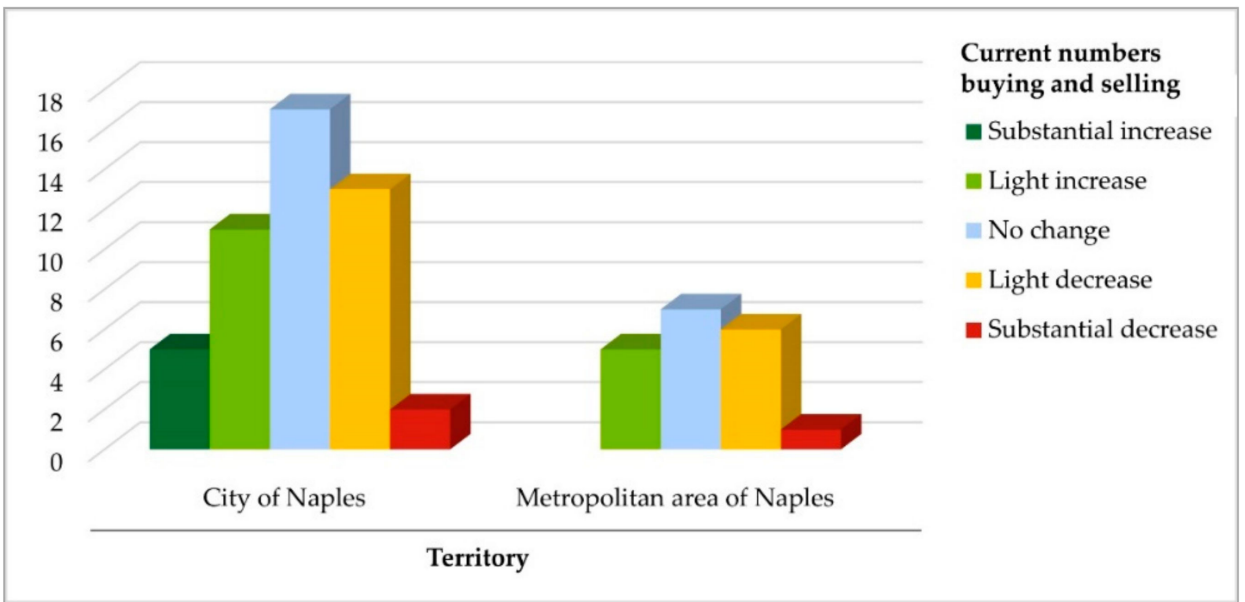

Figure 25. Relationship between territory and current numbers buying and selling.

In terms of the number of pre-lockdown rental requests, $43.5 \%$ of the agents believe that this figure was stationary, $27.5 \%$ think that it was increasing slightly and $28.8 \%$ that it was increasing substantially. However, $7.2 \%$ feel that it was decreasing slightly.

In the lockdown period, on the other hand, this number was stationary for $42.6 \%$ of the agents, substantially up for $30.9 \%$, slightly up for $13.2 \%$, slightly down for $8.8 \%$ and substantially up for $4.4 \%$. At present, however, for the number of rental requests 
compared to the lockdown period, $36.2 \%$ of the agents believe that there had been no change; $26.1 \%$ state that this number is slightly up, $23.2 \%$ state that it is slightly down, $7.2 \%$ state that it is substantially up and $7.2 \%$ state that it is substantially down.

As shown in Figure 26, the number of rental requests changes when considering the City of Naples or the metropolitan area. In fact, while in the metropolitan area many agents report no change, in the City of Naples, the results show a certain balance between a slight increase, no change and a slight decrease. This outcome is likely to depend on the neighbourhood in which each real estate agency operates.

The real estate agents were asked for their opinions on how the residential real estate market is changing in terms of buying and selling. For $34.8 \%$ of the agents, there were no changes due to COVID-19; for 24.6\%, numbers have increased because people are looking for bigger houses due to their changing requirements following the lockdown. For 14.5\%, the numbers have decreased because there are no financial resources to invest. For 8.7\%, the numbers have increased because people want to move to different areas.

In terms of how the residential property market is changing in relation to rentals, $40.6 \%$ of the agents believe that there are no substantial changes and $7.4 \%$ believe that the numbers are increasing because people are experiencing economic problems and cannot afford to buy homes. For $14.5 \%$, the numbers are increasing because people are looking for bigger houses. For $8.7 \%$, the numbers are decreasing because there is a shorter supply of rented houses. For $7.2 \%$, the numbers are increasing because people want to change the area in which they live.

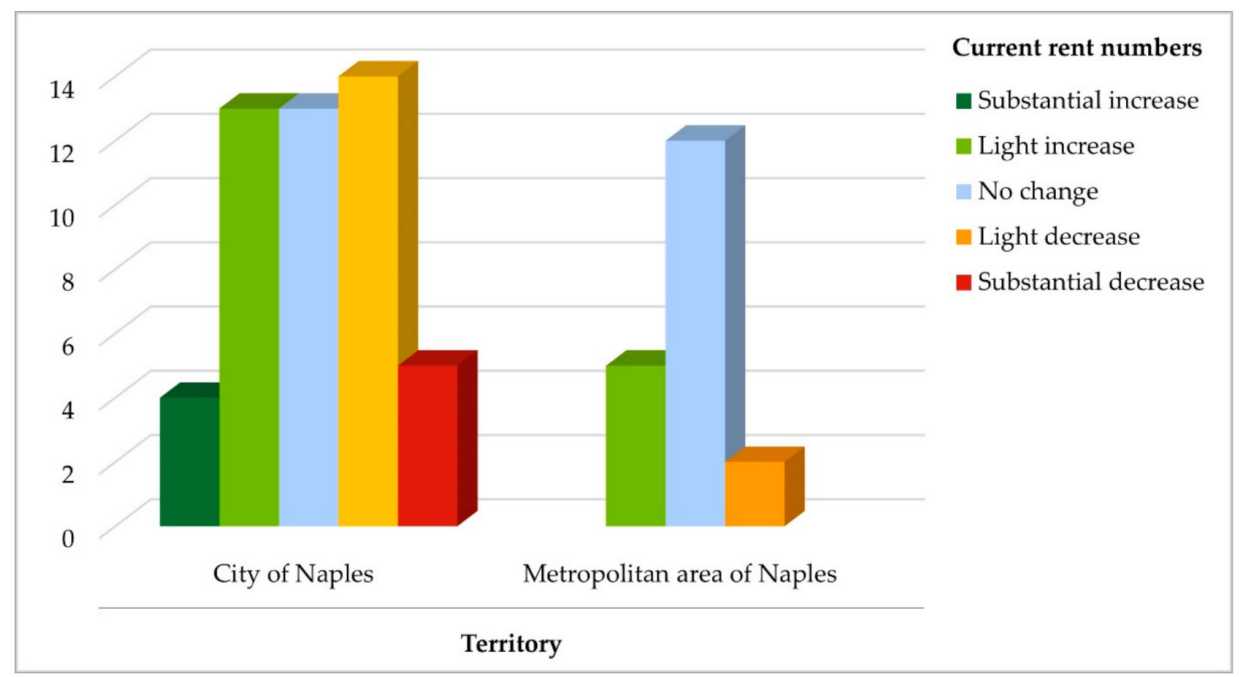

Figure 26. Relationship between territory and current rent numbers.

For real estate agencies, the implementation of activities during the lockdown period necessarily required changes in the provision and organisation of services. Most of the agents involved in the study continued their activities, albeit in alternative ways, as faceto-face meetings were limited. In particular, $56.5 \%$ of the agents continued activities by telephone, internet (video chats and photographs) and virtual visits. Additionally, $27.5 \%$ continued by telephone and internet, but not by virtual visits. The remaining agents did not provide services by alternative means.

These alternative means will continue to be used by $37.7 \%$ of the agents involved in the study, while $52.2 \%$ will continue to use them only partially. However, $5.8 \%$ will not continue to use them, and $4.3 \%$ replied "I do not know".

The most frequently requested contract type was for purchase in the pre-lockdown period $(77.9 \%)$ as well as mid- and post-lockdown periods $(72.1 \%)$. Rent contracts were in lower demand (14.7\% pre-lockdown, $23.5 \%$ mid- and post-lockdown).

More than half $(50.7 \%)$ of the agents who responded find no difference in demand for different urban zones in the pre-, mid- and post-lockdown periods. On the other hand, 
$30.4 \%$ believe that demand referred more to properties in central areas (the data were consistent with the results of the community questionnaire), while $10.1 \%$ feel that demand was for peripheral areas and $8.7 \%$ for semi-central areas.

In addition, the demand for different types of house was analysed to understand whether there were changes between the pre-lockdown and post-lockdown periods (Figure 27). Of the agents, $40.6 \%$ state that there were no changes in the house type requested mid- and post-lockdown compared to the pre-lockdown period. Additionally, 22.7\% state that there was increased demand for single-family houses, and $22.7 \%$ state that there was higher demand for condominium flats.

Of the real estate agents who responded, 73.9\% find higher demand for properties with terraces or gardens. On the other hand, $10.1 \%$ of them reveal increased demand for flats with balconies. For $7.2 \%$, there was no substantial change. The remaining agents report higher demand for properties with shared condominium spaces, shared parking spaces, cellars and panoramic views.

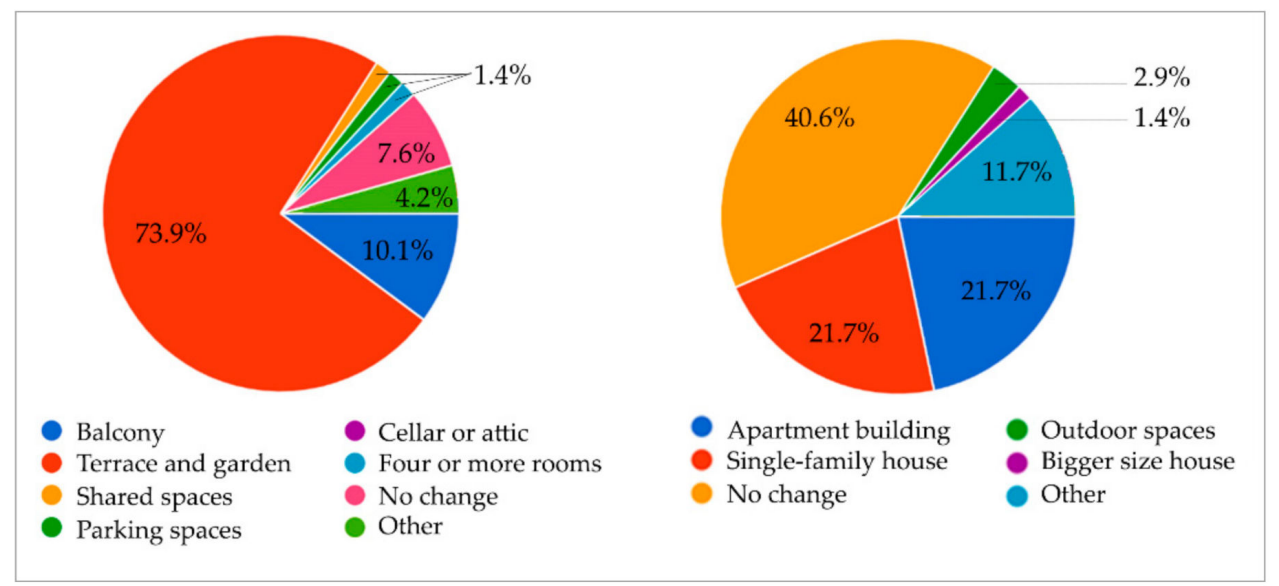

Figure 27. Type of property and characteristics most requested by users mid- and post-lockdown compared to the pre-lockdown period.

The questionnaire also asked what strategies have been considered to overcome the crisis more quickly (open-ended question). On the one hand, some agents feel that it was useful to use the usual operating methodologies without implementing new strategies. Some believe that the recovery of the sector does not depend so much on new strategies but rather on a general economic recovery in the country, which is independent of the real estate market. On the other hand, some agents feel that the need for change is useful. There is a need for more professional training and more digitalisation, and for more advertising (especially on social media). A more in-depth analysis of the changing needs of clients will certainly help to support the recovery from the crisis and to propose more suitable solutions. The virtual aspect is the factor considered to be most important by the agents who responded. In fact, the need to improve and increase virtual tours without neglecting the fundamental interpersonal client relationship (as far as possible) emerges several times in the questionnaire responses.

The last open-ended question is about the substantial elements of change in the residential real estate market observed with respect to the pre-lockdown period. Some agents believe that there will be greater demand for large houses, outdoor spaces and less crowded areas. In addition, according to the agents, digitalisation and virtual tours will allow buyers to have an initial viewing and enable much quicker negotiations. This is also consistent with the results from the community questionnaires, in which $50.3 \%$ of the respondents state that the virtual tour reduces the time taken to buy, sell or rent.

Some agents also highlight the difficulties linked to the possibility of obtaining a mortgage because of the economic difficulties that many Italians are facing, job insecurity and the waves of layoffs due to the general economic crisis in the country. 
Finally, some agents believe that both prices and demand will fall because of uncertainty about the future, which will drive clients to make proposals with a view to making deals. In particular, they believe that there will be a decrease in investors due to the collapse of transitional rentals, which has greatly reduced the profitability of properties compared to the pre-lockdown period.

\section{Discussion and Conclusions}

As in many other sectors, the pandemic in the real estate market has represented a watershed between pre-COVID and post-COVID realities. As highlighted earlier, trends in the real estate market in the pre-COVID period are clear, whereas the post-COVID period can only hint at possible perspectives that are being hypothesised.

Real estate requires changes in order to meet and be useful to a society that is suddenly changing its requirements and to guarantee "fair and sustainable" wellbeing.

The Italian real estate market shows a trend that changed following the 2008 financial crisis (whose effects are still being felt today) and on which the pandemic crisis due to COVID-19 is now grafting. Thus, in the first quarter of 2020, there was a decrease in transactions in the residential market of $15.5 \%$ compared to the same period in 2019.

This change in trend is due to several factors related to the lockdown, including household economic instability and lower incomes, the change in lifestyle and working conditions imposed by the pandemic and the limited activity of real estate agencies. In addition, the decrease in tourism, and therefore in related rents, has also affected the real estate trend in the metropolitan area of Naples.

The pandemic crisis has revealed a structural change in the demand on the characteristics of domestic spaces (and probably will continue after pandemic), expressing the rediscovery of common spaces, such as terraces and condominium parks that are becoming extensions of the houses themselves and the background of a "new sociality" [75]. Larger houses, outdoor spaces and natural lighting are expected to be the characteristics that will be most in demand, as both questionnaire results (from the community and the real estate agents) showed.

The present study has brought out the different perceptions of the community in relation to their changing needs and the views of practitioners in the real estate field.

About $68 \%$ of the interviewed community show some satisfaction with the characteristics of houses, while $27.7 \%$ of the respondents expresses a need for a larger home. The answers concerning a need for "new spaces" are also significant: open spaces (53\%), spaces for leisure activities (33.1\%), spaces for smart working (23.4\%).

Studio apartments that were previously the most popular dwellings in large cities are more difficult to sell today because requirements are different: larger and greener spaces are required, considering the need to spend increasing amounts of time at home.

Dwellings with better natural lighting, better acoustic and thermal insulation, a location on higher floors of the building and more advanced technological equipment are preferred.

After the pandemic, the new approaches are likely to integrate with the traditional ones. Technology, as in other sectors, will play a key role in improving living conditions in apartments (more than half of the respondents agreed with this statement) and in supporting the buying and selling processes (as confirmed by the community and real estate agents). In fact, more than half of the agents answered that they will continue their activities virtually when the health emergency is over. Technology and virtual visits to the houses will help buyers to have an initial viewing and perceptions and thus also reduce "time losses" in the buying and selling processes.

The analysis carried out highlights certain structural changes in the demand for residential properties in the metropolitan area of Naples due to the new requirements as a result of COVID-19. Given that the metropolitan area is fairly saturated in terms of the built environment, it is not possible to implement policies aimed at further urban expansion; instead, recovering abandoned and unused built heritage and disused areas needs to be considered. Therefore, today, there is, in the metropolitan area of Naples, a tendency to 
adapt existing buildings and use those that are currently empty (considering the amount of housing units and buildings highlighted in Section 4.2). This could lead to greater dynamism in the real estate market and a wave of renovations, already currently incentivised by the measures adopted by the Italian government to tackle the COVID-19 crisis (i.e., the aforementioned Eco-bonus). Considering that the built environment is responsible for 39\% of global carbon emissions, this situation could be "used" to tackle climate change, incentivising and adopting renewal solutions from a greener perspective. In order to strengthen the contribution that the real estate market can have in the fight against climate change, it would be necessary to make clearer and more feasible the rules on sustainability in construction and the environment and consequently strengthen the commitment of governments from this perspective and increase their financial investments [76].

Considering that the health emergency is not over yet, the current situation is still very uncertain and unstable. Therefore, the data will continue to change, outlining further perspectives for the future of the real estate market.

This research can continue to collect data and perceptions related to real estate in order to outline prospects in relation to the continuous changes we are now living through due to COVID-19. Continuing to collect and update data and perceptions, adapting them to the evolution of the health situation, makes it possible to orient recovery policies and plans, helping to choose how and where to direct new investments. This analysis also allows the re-orientation of choices and plans already made in a previous context to the particular situation we are experiencing today.

Author Contributions: Conceptualization, P.D.T., F.N.; methodology, P.D.T., F.N., F.B.; data curation, P.D.T., F.B.; formal analyses, P.D.T., F.N.; survey development, P.D.T., F.N., F.B.; analysis of the results, F.N., F.B.; writing—draft, F.N., F.B.; writing-review and editing, P.D.T., F.N., F.B. All authors have read and agreed to the published version of the manuscript.

Funding: This research received no external funding.

Institutional Review Board Statement: Not applicable.

Informed Consent Statement: Each respondent of the questionnaires was explained the aim of the research and the need for data processing, used exclusively for research purposes, while maintaining anonymity.

Data Availability Statement: Used data are available in the references cited in the paper and were processed using ArcGIS software (version 10.7.1).

Acknowledgments: We gratefully thank Vincenzo De Falco (president of the Campania region section of FIMAA (Italian Federation of Business Agent Mediators) and Giuseppe Federici (trainer of the business agent mediators) for their precious support received during the elaboration of this work for the acquisition of data and dissemination of the survey.

Conflicts of Interest: The authors declare no conflict of interest.

\section{References}

1. World Health Organization. WHO Manifesto for a Healthy Recovery from COVID-19: Prescriptions and Actionables for a Healthy and Green Recovery; World Health Organization: Geneva, Switzerland, 2020.

2. Tanrivermis, H. Possible impacts of COVID-19 outbreak on real estate sector and possible changes to adopt: A situation analysis and general assessment on Turkish perspective. J. Urban Manag. 2020, 9, 263-269. [CrossRef]

3. Fusco Girard, L.; Nocca, F. Climate Change and Health Impacts in Urban Areas: Towards Hybrid Evaluation Tools for New Governance. Atmosphere 2020, 11, 1344. [CrossRef]

4. Kholodilin, K.A. Housing Policies Worldwide during Coronavirus Crisis: Challenges and Solutions. Diw Focus 2020, 2. Available online: https://www.diw.de/de/diw_01.c.758176.de/publikationen/diw_focus/2020_0002/housing_policies_worldwide_ during_coronavirus_crisis_challenges_and_solutions.html (accessed on 10 October 2020).

5. Nicolaa, M.; Alsafib, Z.; Sohrabic, C.; Kerwand, A.; Al-Jabird, A.; Iosifidisc, C.; Aghae, M.; Aghaf, R. The socio-economic implications of the coronavirus pandemic (COVID-19): A review. Int. J. Surg. 2020, 78, 185-193. [CrossRef] [PubMed]

6. Allen-Coghlan, M.; McQuinn, K.M. The Potential Impact of Covid-19 on the Irish Housing Sector. Int. J. Hous. Mark. Anal. 2020, in press. Available online: https:/ / www.emerald.com/insight/conten (accessed on 10 October 2020). 
7. Sharifi, A.; Khavarian-Garmsir, A.R. The COVID-19 pandemic: Impacts on cities and major lessons for urban planning, design, and management. Sci. Total Environ. 2020, 749, 142391. [CrossRef] [PubMed]

8. Bauman, Z. Modernità Liquida, 23rd ed.; Laterza: Roma-Bari, Italy, 2008.

9. Dezza, P. Il Real Estate Chiede Misure anti Covid; IlSole24Ore: Milan, Italy, 1 May 2020.

10. Santilli, G. Dal Covid la Città Arcipelago: Più Verde, più aria, Orari Liberi; IlSole24Ore: Milan, Italy, 24 September 2020.

11. De Toro, P.; Gallo, R.; Gerundo, R.; Iodice, S.; Nocca, F. Standards perequation: New perspectives for the realization of services for the city. Sustain. Mediterr. Constr. 2020, 12, 125-131.

12. González Pérez, J.M.; Piñeira Mantiñán, M.J. The unequal city in Palma (Majorca): Geography of confinement during the COVID-19 pandemic. Boletín Asoc. Geógrafos Españoles 2020. [CrossRef]

13. Checa, J.; Martín, J.; López, J.; Nello, O. Los que no pueden quedarse en casa: Movilidad urbana y vulnerabilidad territorial en el área metropolitana de Barcelona durante la pandemia COVID-19. Boletín Asoc. De Geógrafos Españoles 2020. [CrossRef]

14. Coronavirus: An Architect on How the Pandemic Could Change Our Homes Forever. Available online: https://theconversation. com/coronavirus-an-architect-on-how-the-pandemic-could-change-our-homes-forever-138649 (accessed on 15 January 2021).

15. JLL Research \& Strategy. COVID-19: Global Real Estate Implications, Paper II; Global Research: Hillsborough, UK, 20 April 2020. Available online: https://www.jll.it/it/tendenze-e-ricerca/research/covid-19-global-real-estate-implications (accessed on 13 November 2020).

16. PricewaterhouseCoopers Advisory SpA (PwC). Impatti del COVID-19 sul Real Estate: Come Rispondere Rapidamente; London, UK, 2020. Available online: https:/ / www.pwc.com/it/it/publications/assets/docs/PwC-Italia-Real-Estate-impatti-del-covid-19 -Checkup.pdf (accessed on 13 November 2020).

17. Engel \& Völkers. Report sul Mercato Immobiliare Post COVID-19; Engel \& Völkers Padova: Padova, Italy, 2020. Available online: https: //www.engelvoelkers.com/it-it/padova/blog/report-sul-mercato-immobiliare-post-covid-19/ (accessed on 20 November 2020)

18. Pickford, J. Coronavirus Fears Hit UK Property Market as Viewings Dry Up; Financial Times: London, UK, 17 March 2020. Available online: https:/ / www.ft.com/content/e30ccb84-6799-11ea-800d-da70cff6e4d3 (accessed on 13 November 2020).

19. Scenari Immobiliari. FUTU.RE Report, COVID-19 e l'impatto sul Mondo dei Servizi Immobiliari. June 2020. Available online: https:/ / www.scenari-immobiliari.it/shop/futu-re-covid-19-elimpatto-sul-mondo-dei-servizi-immobiliari/ (accessed on 13 November 2020).

20. Dezza, P. La Rigenerazione Urbana Potrà Essere il Motore Della Ripresa Post Covid-19; IlSole24Ore: Milan, Italy, 23 September 2020.

21. Italian Federation of Professional Real Estate Agents (FIAIP). Osservatorio Immobiliare Nazionale Settore Urbano 2019; Italian Federation of Professional Real Estate Agents: Rome, Italy, 2019. Available online: https://ilmercatoimmobiliare.altervista. org/osservatorio-immobiliare-nazionale-settore-urbano-tra-crescita-nel-2019-e-le-conseguenze-dellemergenza-coronavirus / (accessed on 13 November 2020).

22. Real Estate Market Observatory (OMI). Rapporto Immobiliare 2019, il Settore Residenziale; Services Division, Estimation Services Central Management and Real Estate Market Observatory: Rome, Italy, 2019. Available online: https: //www.agenziaentrate.gov.it/portale/documents/20143/263076/rapporto+immobiliare2019+ri_RI2019_Residenziale_201905 23.pdf/a175f856-2363-dda7-da64-b1c0e544eb12 (accessed on 20 November 2020).

23. Il Mercato delle Locazioni Residenziali-Continuano a Crescere i Canoni in Tutte le Grandi Città. Available online: https: / / www.aspesi-associazione.it/news.asp?idn=35727 (accessed on 20 November 2020).

24. Locazione Come Scelta Abitativa in Forte Aumento. Available online: https://news.tecnocasagroup.it/ufficio-stampa/ comunicati-stampa/mercato-nazionale-e-attualita/analisi-socio-demografica-locazioni-iisem2019/ (accessed on 5 October 2020).

25. Statistical Office of the European Union (Eurostat). Housing Price Statistics: Newsrelease Euroindicators; European Commission: Brussels, Belgium, 2020. Available online: https: / / ec.europa.eu/eurostat/documents / portlet_file_entry/2995521/2-08042020 -AP-EN.pdf/d624aabc-eca8-029c-868b-f80efec5b89a (accessed on 7 October 2020).

26. Italian National Institute for Environmental Protection and Research (ISPRA). XIII Rapporto Qualità Dell'ambiente Urbano, 2017 ed.; Rome, Italy, 2017. Available online: https:/ / www.isprambiente.gov.it/it/pubblicazioni/stato-dellambiente/xiii-rapportoqualita-dell2019ambiente-urbano-edizione-2017 (accessed on 7 October 2020).

27. Department for Regional Affairs and Autonomies (DARA). I Dossier Delle Città Metropolitane. Città Metropolitana di Napoli, 1st ed.; Naples, Italy, 2017. Available online: http:/ / www.affariregionali.it/comunicazione/dossier-e-normativa/i-dossier-delle-citt\%C3 $\%$ A0-metropolitane/ (accessed on 12 October 2020).

28. Metropolitan City of Naples. Piano Strategico della Città Metropolitana di Napoli. Available online: https://www. cittametropolitana.na.it/strategie (accessed on 12 October 2020).

29. Italian National Institute of Statistic (ISTAT). Il Benessere Equo e Sostenibile in Italia. BES Report 2015; Italian National Institute of Statistic: Rome, Italy, 2015.

30. Italian National Institute of Statistic (ISTAT). Il Benessere Equo e Sostenibile in Italia. BES Report 2019; Italian National Institute of Statistic: Rome, Italy, 2019.

31. Fusco Girard, L.; Cerreta, M.; De Toro, P.; Nocca, F.; Poli, G.; Buglione, F.; Regalbuto, S.; Muccio, E.; Romano, F. L’Economia Circolare Nella Rigenerazione Delle Risorse Ambientali, Culturali e Paesaggistiche Delle Città Metropolitane portuali: Sfide, Strategie, Modelli di Valutazione; PRIN 2015 Research Report, University of Naples Federico II, Naples, Italy. Unpublished work, 2020. 
32. Italian Federation of Business Agents Mediators (FIMAA) of Naples. Quotazioni Metroquadro Napoli e Provincia; Real Estate Agents: Naples, Italy, 2019.

33. Italian National Institute of Statistic (ISTAT). Edifici per Stato d'uso, in Censimento ISTAT; Italian National Institute of Statistic: Rome, Italy, 2011.

34. Andamento dei Prezzi Degli Immobili Nella Provincia di Napoli. Available online: https://www.immobiliare.it/mercatoimmobiliare/campania/napoli-provincia/ (accessed on 12 October 2020).

35. De Falco, V. Nell'anno della pandemia da Covid-19 Fimaa resta la bussola del consumatore. In Quotazioni Metroquadro Napoli e Provincia; Real Estate Agents: Naples, Italy, November 2020.

36. Osservatorio Immobiliare Nella Città Metropolitana di Napoli, Quotazioni Immobiliari e News sul Mercato Immobiliare Nella Città Metropolitana di Napoli. Available online: https:/ / www.mercato-immobiliare.info/campania/napoli.html (accessed on 12 October 2020).

37. Italian Federation of Business Agents Mediators (FIMAA) of Naples. Quotazioni Metroquadro Napoli e Provincia; Real Estate Agents: Naples, Italy, 2020.

38. Naples Real Estate Exchange. Official Catalog; Chamber of Commerce, Industry, Crafts and Agriculture: Naples, Italy, 2009-2018.

39. Jenks, G.F. The data model concept in statistical mapping. Int. Yearb. Cartogr. 1967, 7, 186-190.

40. Mercato immobiliare, Tecnocasa: Nel 2019 compravendite in calo del 2.4\% a Napoli. Available online: https:/ /www.ildenaro.it/ mercato-immobiliare-tecnocasa-nel-2019-compravendite-in-calo-del-24-a-napoli/ (accessed on 12 October 2020).

41. Mercato immobiliare Napoli, II Semestre 2019. Available online: https:/ / news.tecnocasagroup.it/ufficio-stampa / comunicatistampa/mercato-immobiliare-locale/mercato-immobiliare-napoli-ii-semestre-2019/ (accessed on 12 October 2020).

42. Osservatorio Immobiliare, per Nomisma Segnali di Ripresa dal 2022. Available online: https://www.idealista.it/news/ immobiliare/residenziale/2020/11/25/151868-osservatorio-immobiliare-per-nomisma-segnali-di-ripresa-dal-2022 (accessed on 20 October 2020).

43. Istat: Marcata Contrazione del Pil nel 2020, Ripresa Parziale nel 2021. Available online: https://www.ansa.it/sito/notizie/ economia/2020/06/08/istat-marcata-contrazione-del-pil-nel-2020-ripresa-parziale-nel-2021_752c65ee-1e62-4426-9f51-4ae5 7cda4db6.html (accessed on 20 October 2020).

44. Lovera, A. Sarà il Residenziale il Primo a Ripartire Nella Fase Post Covid; IlSole24Ore: Milan, Italy, 29 June 2020.

45. Mercato Immobiliare Colpito, ma non Affondato. Available online: https://www.scenari-immobiliari.it/2020/05/13/mercatoimmobiliare-colpito-ma-non-affondato/ (accessed on 20 October 2020).

46. Real Estate Market Observatory (OMI). Rapporto Immobiliare 2020, il Settore Residenziale; Services Division, Estimation Services Central Management and Real Estate Market Observatory: Rome, Italy, 2020. Available online: https:/ /www.agenziaentrate.gov.it/ portale/web/guest/schede/fabbricatiterreni/omi/pubblicazioni/rapporti-immobiliari-residenziali (accessed on 20 October 2020).

47. Marchesini, E. Per il Real Estate Rimbalzo nel 2021. Case, Prezzi In Calo; IlSole24Ore: Milan, Italy, 7 September 2020.

48. Gabetti\&Patrigest. Real Estate. I Trend Post Covid Settore per Settore; Gabetti Property Solutions: Milan, Italy, 2020. Available online: http:/ / www.gabettigroup.com/it-it/ufficio-studi/dettaglio-tutti-i-report/artmid/1106/articleid/1001/real-estate-itrend-post-covid-settore-per-settore-2020 (accessed on 13 October 2020).

49. Mercato Immobiliare Dopo il Covid, le Previsioni dal 2020 al 2025. Available online: https://www.idealista.it/news/finanza/ investimenti/2020/06/23/147090-mercato-immobiliare-dopo-il-covid-le-previsioni-dal-2020-al-2025 (accessed on 20 October 2020).

50. Valutare Nell'incertezza. Un Modello Previsivo 2020-2025. Available online: https://www.scenari-immobiliari.it/2020/04/30 / valutare-nellincertezza-un-modello-previsivo-2020-2025/ (accessed on 20 October 2020).

51. Santilli, G. L'Ance Scommette sul Bazooka: Vale 6 Miliardi di Lavori; IlSole24Ore: Milan, Italy, 8 May 2020.

52. Mobili, M. Superbonus 110\%, le Regole Finali; IlSole24Ore: Milan, Italy, 4 July 2020.

53. Santilli, G. Ecobonus 110\%, Corsa al via. Cosa si può Fare e Come; IlSole24Ore: Milan, Italy, 15 May 2020.

54. Italian Federation of Professional Real Estate Agents (FIAIP). "Sorpresa, l'immobiliare Regge. Richieste di Prima Casa a +15\%"; LaStampa: Turin, Italy, 18 June 2020; p. 17.

55. Dezza, P. Real Estate, la Rivoluzione Verde Prende Forma; IlSole24Ore: Milan, Italy, 15 May 2020.

56. Degli Innocenti, N. Knight Frank Rivoluziona le Previsioni: Vienna e Lisbona Vincono sul Covid; IlSole24Ore: Milan, Italy, 6 May 2020.

57. Covid e Mercato Immobiliare, le Previsioni di Nuveen Real Estate per l'Europa. Available online: https://www.idealista.it/news / finanza/investimenti/2020/05/11/140236-covid-e-mercato-immobiliare-le-previsioni-di-nuveen-real-estate-per-leuropa (accessed on 26 October 2020).

58. Real Estate Market Observatory (OMI). Residenziale. Statistiche I trimestre 2020; Services Division, Estimation Services Central Management and Real Estate Market Observatory: Rome, Italy, 2020. Available online: https://www.agenziaentrate.gov.it/ portale/documents /20143/262485/StatisticheOMI_RES_1_2020_20200605.pdf/3af07746-906c-45af-5853-da521605de03 (accessed on 9 November 2020).

59. Gabetti. Residential Snapshot Q1 2020; Gabetti Property Solutions: Milan, Italy, 2020. Available online: http:/ / www.gabettigroup.com/ it-it/ufficio-studi/dettaglio-tutti-i-report/artmid/1106/articleid/996/residential-snapshot-q1-2020 (accessed on 9 November 2020).

60. Italian National Institute of Statistic (ISTAT). Prezzi Delle Abitazioni. II Trimestre 2020; Italian National Institute of Statistic: Rome, Italy, 2020. Available online: https:/ / www.istat.it/it/files//2020/09/CS-abitazioni-Q22020.pdf (accessed on 10 November 2020).

61. Il Mattone Batte il Virus, Nonostante il clima Economico Negativo. Available online: https:/ / www.aspesi-associazione.it/news. asp?idn=35781 (accessed on 12 November 2020). 
62. Mercato Immobiliare Italiano Post Covid-19: La voglia di Acquistare casa non Viene Meno. Available online: https: / / www.lavoripubblici.it/news/2020/07/STIME-E-IMMOBILI/24048/Mercato-immobiliare-italiano-post-Covid-19-Lavoglia-di-acquistare-casa-non-viene-meno (accessed on 12 November 2020).

63. Gli Effetti del Lockdown si Fanno Sentire. Available online: https://news.tecnocasagroup.it/ufficio-stampa/comunicati-stampa/ mercato-nazionale-e-attualita/compravendite-residenziali-primo-trimestre-2020/ (accessed on 12 November 2020).

64. Cavestri, L. Università, la Partenza Incerta fa Tremare il Mercato Degli Affitti; IlSole24Ore: Milan, Italy, 30 August 2020.

65. Lovera, A. Affitti per Studenti, il 43\% dei Proprietari Pronto allo Sconto; IlSole24Ore: Milan, Italy, 14 September 2020.

66. Dezza, P. Affitti Brevi Torna l'incubo Covid; IlSole24Ore: Milan, Italy, 24 September 2020.

67. Prezzi e Locazioni Immobiliari, Cosa è Cambiato con il Covid. Available online: https:/ /www.idealista.it/news/immobiliare/ residenziale/2020/07/27/149791-prezzi-e-locazioni-immobiliari-cosa-e-cambiato-con-il-covid (accessed on 12 November 2020).

68. Deganello, S. Ecco la Casa Ibrida, Pronta a Tutti gli usi; IlSole24Ore: Milan, Italy, 17 May 2020.

69. LaRepubblicaEconomia. Lockdown, Caccia alla casa Vacanze. I prezzi Vantaggiosi Spingono le Vendite; LaRepubblica: Rome, Italy, 28 December 2020.

70. Leone, C. L'impatto della pandemia da Covid-19 nel mercato del credito alle famiglie. In Quotazioni Metroquadro Napoli e Provincia; Real Estate Agents: Naples, Italy, November 2020.

71. Italian Association of Real Estate Development and Property Companies (ASPESI). Nota Mensile n. 2-Maggio 2020. Available online: http:/ / www.aspesi-associazione.it/public/files/2020/Centro-Studi-FIAIP-nota-congiunturale_-maggio-2020.pdf (accessed on 16 November 2020).

72. Santilli, G. Superbonus 110\%, gli Interventi Crescono con più Proprietari; IlSole24Ore: Milan, Italy, 8 May 2020.

73. IlSole24Ore. L'immobiliare ai Tempi del Covid. Così Tempocasa ce l'ha Fatta; IlSole24Ore: Milan, Italy, 30 August 2020.

74. Lovera, A. Il proptech non si Ferma Neanche con il Covid; IlSole24Ore: Milan, Italy, 4 May 2020.

75. Marrazzo, D. Un po' Palcoscenico, Palestra e Altare: Quanta Nuova vita c'è su Tetti e Terrazzi; IlSole24Ore: Milan, Italy, 31 August 2020.

76. Pike, J. The Future of Sustainable real Estate Investments in a Post-COVID-19 World. J. Eur. Real Estate Res. 2020, in press. Available online: https://www.researchgate.net/publication/343291835_The_future_of_sustainable_real_estate_investments_ in_a_post-COVID-19_world (accessed on 19 November 2020). 